\title{
Bio-Mimetic Catalase-like Activity, Corrosion Inhibition, Antibacterial, DFT and Spectroscopic Characterization of Mixed Ligand Complexes of 1,10-Phenanthroline with Dibasic Benzoin Schiff Base Ligand
}

\author{
SATYENDRA N. SHUKLA*, PRATIKSHA GAUR, PREETI VAIDYA, \\ BHASKAR CHAURASIA, SANGEETA JHARIYA and DIMPLE DEHARIYA \\ Coordination Chemistry Research Lab, \\ Department of Chemistry, Government Science College, Jabalpur (M.P.) 482001, India \\ sns1963_1@rediffmail.com
}

Received 20 March 2018 / Accepted 3 April 2018

\begin{abstract}
Four novel mix ligand complexes of manganese(II), iron(III), cobalt(II) and nickel(II) with dibasic tetra dentate Schiff base ligand BENZOEN and 1, 10-phenanthroline have been synthesized with the general composition of $[\mathrm{M}(\mathrm{BENZOEN})(1,10-\mathrm{phen})]$, where $\mathrm{M}=\mathrm{Mn}(\mathrm{II})$, $\mathrm{Co}(\mathrm{II}), \mathrm{Ni}(\mathrm{II})$ and $[\mathrm{Fe}(\mathrm{BENZOEN})(1,10-$ phen $)] \mathrm{Cl}$. The synthesized ligand and complexes were characterized on the basis of elemental analysis, molar conductance, magnetic susceptibility, ESIMS spectrometry, electronic spectra, FT-IR, ${ }^{1} \mathrm{H}$ NMR and ${ }^{13} \mathrm{C}$ NMR spectroscopy. Theoretical computation and combined experimental theoretical characterization were carrying out by Gaussian 09 software package using density functional theory (DFT) method to confirm the geometry of the investigated compounds. Additionally, molecular electrostatic potential map (MEP), HOMO, LUMO, NBO and Mullikan charge analysis were also been performed. Spectroscopic chracterization and DFT study proposed a distorted octahedral structure of complex 1-4. In vitro biomimetic catalase activity of the ligand and complexes was done by measuring amount of dioxygen evolve. Saturation kinetics of $\mathrm{H}_{2} \mathrm{O}_{2}$ decomposition was fitted to the Michaelis-Menten equation and Lineweaver-Burk plot. The antibacterial activity of the ligand and complexes against Escherichia coli shows complexes were found more potent than the BENZOEN. MIC of complexes shows that complex $\mathbf{2}$ is more active than other complexes even at lower concentration.
\end{abstract}

Keywords: Dibasic tetradentate Schiff base, Biomimetic, Catalase activity, Enzyme Kinetics, DFT study, Corrosion inhibition

\section{Introduction}

Recently mixed ligand complexes of manganese, iron, cobalt and nickel with N,O donor Schiff base and bipyridyl like 1, 10-phenanthroline have attracted great interest, owing to their 
significant roles in the advancement of biomedicine ${ }^{1}$, bio-sensors ${ }^{2}$, corrosion inhibitors $^{3}$, model compounds for active centers of metalloenzymes ${ }^{4}$ and in homogeneous and heterogeneous catalytic reactions of industrial importance ${ }^{5}$. These complexes have also exhibits wide range of biological and pharmaceutical activities that include antimicrobial, antituberculosis, antiinflammatory, anticancer and antioxidant behavior ${ }^{6,7}$.

In human as a byproduct of respiration, digestion and other every day biological activities various reactive oxygen species (ROS), produced in the body such as hydrogen peroxide, which is responsible for "oxidative stress". It is a biological poison and it attacks tissues, membranes and behave as lethal agents against cell structure and functioning leading to irreversible cell damage and severe pathologies. Catalase is enzymes that protect cells from oxidative damage by scavenging the hydrogen peroxide or superoxide radicals produced during dioxygen reduction ${ }^{8-10}$.

Various structural models of manganese, iron, cobalt and nickel containing enzymes have helped a lot in exploring various aspects of transition metal complex chemistry on the basis of structure, electrochemical and magnetic properties which in turn had give rise in the development of these complexes with instant applications in magnetic, biochemical and catalytic chemistry ${ }^{11-13}$. In the last five years aromatic, $N, N$-ligands, 1,10-phenanthroline and its various derivatives have been studied extensively due to their versatility and diverse biological properties i.e., antibacterial, antifungal, antiviral and anti-micoplasma ${ }^{14-16}$. Benzoin and ethylenediamine have also exhibit immense synthetic and analytical applications ${ }^{17,18}$. Furthermore, with increasing of microbial resistance to current antibiotics, there is continues demand for developing new antimicrobial agents. In this way, many $\mathrm{Mn}(\mathrm{II}), \mathrm{Fe}(\mathrm{III}), \mathrm{Co}(\mathrm{II})$ and $\mathrm{Ni}(\mathrm{II})$ complexes have been reported as more effective antimicrobial agents ${ }^{19}$.

Therefore, in anticipation of good reactivity and biological activity we thought it will be worthy to synthesize a symmetric ligand by reaction of benzoin with linker ethylenediamine and its complexes with selected transition metals viz., manganese, iron, cobalt and nickel. The resulting complexes will be characterized spectroscopically and explored for their biomimetic catalase like activity, anticorrosive and antibacterial activity.

\section{Experimental}

Ethylenediamine, benzoin, manganese(II) chloride, ferric(III) chloride, cobalt(II) chloride, nickel(II) chloride and 1, 10-phenanthroline (All E. Merck). Analytical reagent grade solvents were distilled before use. Conductivity measurements were carried out at $25{ }^{\circ} \mathrm{C}$ on an EI-181 conductivity bridge with dipping type cell. ESI-MS spectra were recorded on Agilent-6520 (Q-TOF) mass spectrometer. FT-IR spectra were recorded in KBr pellets on Shimadzu - 8400 PC. Electronic absorption spectra were recorded in EI-2305, double beam spectrophotometer equipped with a PC. ${ }^{1} \mathrm{H}$ NMR and ${ }^{13} \mathrm{C}$ NMR spectrum was recorded in Bruker Avance 400 (FT NMR). The metal contents were analyzed gravimetrically by the literature procedure ${ }^{20}$.

Synthesis of (2Z)-2-((E)-2-(1,2-diphenylethylideneamino)ethylimino)-1,2-diphenylethanol (BENZOEN)

Benzoin (4.24 g, $0.02 \mathrm{~mol})$ in $25 \mathrm{~mL}$ methanol was added in solution of ethylenediamine $(0.67 \mathrm{~mL}, 0.01 \mathrm{~mol})$ in $10 \mathrm{~mL}$ of methanol in a flat bottom flask and the resulting mixture was stirred for $1 \mathrm{~h}$. Thereafter, reaction mixture was kept under reflux for $14 \mathrm{~h}$ in an inert atmosphere. Progress of the reaction was monitored by TLC. After completion reaction, mixture was concentrated by evaporating the solution to half of its volume. The concentrated solution was poured into crushed ice. A brownish yellow solid was obtained, 
it was filtered off, washed several times with methanol and recrystallized from 1:2, methanol: water. Crystalline brownish yellow solid was obtained which was dried in a esiccators over anhydrous calcium chloride under vacuum. Colour $=$ Brownish yellow, Yield: $3.92 \mathrm{~g}(92.45 \%)$; m. p. $=220^{\circ} \mathrm{C}$, Anal calculated formula $\mathrm{C}_{30} \mathrm{H}_{28} \mathrm{~N}_{2} \mathrm{O}_{2}(\mathrm{M} \tau=448.22)$ : C, 80.33; H, 6.29; N, 6.25. Found: C, 80.20; H, 6.27; N, 6.00. Selected infrared absorption $\left(\mathrm{KBr}, \mathrm{cm}^{-1}\right): v(\mathrm{O}-\mathrm{H}), 3192(\mathrm{w}) ; \mathrm{v}(\mathrm{C}=\mathrm{N})_{\text {imine }}, 1604(\mathrm{~s}) ; \mathrm{v}\left(\mathrm{CH}_{2}-\mathrm{CH}_{2}\right), 923(\mathrm{~s})$. Electronic spectra $\left(\lambda_{\max }\right.$ in $\mathrm{nm}\left(\varepsilon\right.$ in mol L $\left.{ }^{-1} \mathrm{~cm}^{-1}\right)$ in DMF: $360(3235) ; 280(1894) .{ }^{1} \mathrm{H}$ NMR spectra $(\delta$ value in ppm): $\delta(\mathrm{O}-\mathrm{H})_{\text {phenolic }}, 12.03(\mathrm{~s}, 2 \mathrm{H}) ; \delta(\mathrm{Ar}-\mathrm{H})_{\text {benzene }}, 7.980(\mathrm{~s}, 2 \mathrm{H}), 7.938(\mathrm{~s}, 2 \mathrm{H}), 7.890(\mathrm{~s}, 2 \mathrm{H})$, 7.800(s, 2H), 7.798(s, 2H), 7.664-7.653(t, 4H, $J=2.8 \mathrm{~Hz}, 1.6 \mathrm{~Hz}), 7.453(\mathrm{~d}, 2 \mathrm{H}), 7.239(\mathrm{~s}$, $1 \mathrm{H}), 7.102(\mathrm{~s}, 1 \mathrm{H}), 7.004(\mathrm{~d}, 1 \mathrm{H}, J=3.6 \mathrm{~Hz}), 6.99(\mathrm{~d}, 1 \mathrm{H}) ; \delta(\mathrm{C}-\mathrm{H}), 4.03(\mathrm{~s}, 2 \mathrm{H})$ and $\delta\left(-\mathrm{CH}_{2}\right)$, $3.40(\mathrm{~d}, 2 \mathrm{H}, J=4.8 \mathrm{~Hz}) .{ }^{13} \mathrm{C}$ NMR spectra $\left(\delta\right.$ value in ppm): $\delta(>\mathrm{C}=\mathrm{N})_{\text {imine }}, 176.12 ; \delta(\mathrm{C}-\mathrm{OH})$, $165.13 ; \quad \delta(\mathrm{Ar}-\mathrm{C})_{\text {benzene, }}, 115.91-136.26 ; \quad \delta\left(\mathrm{CH}_{2}-\mathrm{CH}_{2}\right), \quad 48.92$. ESI-Mass spectra, $\mathrm{m} / z$ : $\left[\mathrm{C}_{15} \mathrm{H}_{14} \mathrm{NO}+\mathrm{H}^{+}\right]^{+}=225.18, \quad\left[\mathrm{C}_{23} \mathrm{H}_{21} \mathrm{~N}_{2} \mathrm{O}+\mathrm{H}^{+}\right]^{+}=342.16, \quad\left[\mathrm{C}_{24} \mathrm{H}_{23} \mathrm{~N}_{2} \mathrm{O}_{2}+\mathrm{H}^{+}\right]^{+}=372.19$, $\left[\mathrm{C}_{30} \mathrm{H}_{28} \mathrm{~N}_{2} \mathrm{O}_{2}+\mathrm{H}^{+}\right]^{+}=449.22, \mathrm{M} \tau=448.22$.

\section{Synthesis of [Mn(BENZOEN)(1,10-phen)]; Complex 1}

1,10-Phenanthroline $(0.180 \mathrm{~g}, 0.001 \mathrm{~mol})$ in $10 \mathrm{~mL}$ ethanol was added to $\mathrm{MnCl}_{2} \cdot 4 \mathrm{H}_{2} \mathrm{O}$ $(0.161 \mathrm{~g}, 0.001 \mathrm{~mol})$ in $15 \mathrm{~mL}$ ethanol and the solution was stirred initially for $15 \mathrm{~min}$. Thereafter, BENZOEN (0.448 g, $0.001 \mathrm{~mol})$ in $25 \mathrm{~mL}$ hot ethanol was added and the resulting reaction mixture was stirred for $1 \mathrm{~h}$ in an inert atmosphere. A orange precipitate was obtained after refluxing the reaction mixture for $10 \mathrm{~h}$. The precipitate obtained was filtered, washed several times with acetone, recrystallized from hot methanol and dried in a desiccator over anhydrous calcium chloride under vacuum. Colour $=$ Orange, Yield: $0.473 \mathrm{~g}$ (60.11\%); m.p. > $280{ }^{\circ} \mathrm{C}$; Anal Calc. for $\mathrm{C}_{42} \mathrm{H}_{34} \mathrm{MnN}_{4} \mathrm{O}_{2}(\mathrm{M} \tau=681.21)$ : C, 74.00; H, 5.49; N, 9.54; Mn, 8.06. Found: C, 73.90; H, 5.41; N, 9.39; Mn, 7.94. $\mu_{\text {eff }}=2.45$ B.M. Molar conductance $\Lambda_{\mathrm{m}}$ at $25{ }^{\circ} \mathrm{C}\left(\Omega^{-1} \mathrm{~cm}^{2} \mathrm{~mol}^{-1}\right): 14$ in DMSO. Selected infrared absorption (KBr, $\left.\mathrm{cm}^{-1}\right): v(\mathrm{C}-\mathrm{H})_{\text {arom }}, 3059(\mathrm{~m}) ; \quad v(\mathrm{C}=\mathrm{N})_{\text {cyclic }}, 1699(\mathrm{w}) ; v(\mathrm{C}=\mathrm{N})_{\text {imine }}, 1589(\mathrm{~m}) ; v\left(\mathrm{CH}_{2}-\mathrm{CH}_{2}\right)$, $887(\mathrm{~s}) ; \mathrm{v}(\mathrm{M}-\mathrm{O}), 565(\mathrm{~s}) ; \mathrm{v}(\mathrm{M}-\mathrm{N}), 459(\mathrm{~s})$. Electronic spectra $\left(\lambda_{\max }\right.$ in $\mathrm{nm}\left(\varepsilon\right.$ in $\left.\left(\mathrm{mol} \mathrm{L}^{-1} \mathrm{~cm}^{-1}\right)\right)$ in DMF: 740 (221); 640 (211); 540 (225); 440 (1742); 260 (325); ESI-Mass spectra, $m / z$ : $\left[\mathrm{C}_{12} \mathrm{H}_{8} \mathrm{~N}_{2}+\mathrm{H}^{+}\right]^{+}=181.06,\left[\mathrm{C}_{12} \mathrm{H}_{8} \mathrm{MnN}_{2}+\mathrm{H}^{+}\right]^{+}=236.01,\left[\mathrm{C}_{30} \mathrm{H}_{26} \mathrm{~N}_{2} \mathrm{O}_{2}+3 \mathrm{H}^{+}\right]^{+}=449.21$, $\left[\mathrm{C}_{30} \mathrm{H}_{26} \mathrm{MnN}_{2} \mathrm{O}_{2}+\mathrm{H}^{+}\right]^{+}=502.14,\left[\mathrm{C}_{42} \mathrm{H}_{34} \mathrm{MnN}_{4} \mathrm{O}_{2}+\mathrm{H}^{+}\right]^{+}=682.21, \mathrm{M} \tau=681.21$.

\section{Synthesis of [Fe(BENZOEN)(1,10-phen)]Cl; Complex 2}

1,10-Phenanthroline $(0.180 \mathrm{~g}, 0.001 \mathrm{~mol})$ in $10 \mathrm{~mL}$ ethanol was added to a solution containing $\mathrm{FeCl}_{3}(0.162 \mathrm{~g}, 0.001 \mathrm{~mol})$ in $15 \mathrm{~mL}$ ethanol and the solution was stirred initially for $15 \mathrm{~min}$. Thereafter, BENZOEN $(0.448 \mathrm{~g}, 0.001 \mathrm{~mol})$ in $25 \mathrm{~mL}$ hot ethanol was added and the resulting reaction mixture was stirred for $1 \mathrm{~h}$ in an inert atmosphere. A dark red precipitate was obtained after refluxing the reaction mixture for $8 \mathrm{~h}$. The solid obtained was filtered, washed several times with acetone and recrystallized from hot methanol to yield dark red crystalline solid. The recrystallized solid was dried in a desiccator over anhydrous calcium chloride under vacuum. Colour $=$ Dark red, Yield: 0.494 g (62.70\%); m.p. $>280{ }^{\circ} \mathrm{C}$; Anal. Calc. for $\mathrm{C}_{42} \mathrm{H}_{34} \mathrm{FeN}_{4} \mathrm{O}_{2} \mathrm{Cl}$ $(\mathrm{M} \tau=717.17): \mathrm{C}, 70.25 ; \mathrm{H}, 4.77 ; \mathrm{N}, 7.80 ; \mathrm{Fe}, 7.78$. Found: $\mathrm{C}, 70.12 ; \mathrm{H}, 4.73 ; \mathrm{N}, 7.73 ; \mathrm{Fe}$, 7.70. $\mu_{\text {eff }}=2.81$ B.M. Molar conductance $\Lambda_{\mathrm{m}}$ at $25^{\circ} \mathrm{C}\left(\Omega^{-1} \mathrm{~cm}^{2} \mathrm{~mol}^{-1}\right): 66$ in DMSO. Selected infrared absorption $\left(\mathrm{KBr}, \mathrm{cm}^{-1}\right): v(\mathrm{C}-\mathrm{H})_{\text {arom }}, 3048(\mathrm{~s}) ; \mathrm{v}(\mathrm{C}=\mathrm{N})_{\text {cyclic, }} 1645(\mathrm{~m}) ; \mathrm{v}(\mathrm{C}=\mathrm{N})_{\text {imine }}$, 1586(sh); $v\left(\mathrm{CH}_{2}-\mathrm{CH}_{2}\right), 932(\mathrm{~m}) ; v(\mathrm{M}-\mathrm{O}), 569(\mathrm{w}) ; v(\mathrm{M}-\mathrm{N}), 443(\mathrm{~s})$. Electronic spectra $\left(\lambda_{\max }\right.$ in $\mathrm{nm}\left(\varepsilon\right.$ in $\left.\left(\mathrm{mol} \mathrm{L}^{-1} \mathrm{~cm}^{-1}\right)\right)$ in DMF: 540 (23); 460 (20); 320 (545); 240 (325). ESI-Mass spectra, $m / z:\left[\mathrm{C}_{12} \mathrm{H}_{8} \mathrm{~N}_{2}+\mathrm{H}^{+}\right]^{+}=181.07,\left[\mathrm{C}_{12} \mathrm{H}_{8} \mathrm{FeN}_{2}+\mathrm{H}^{+}\right]^{+}=237.01,\left[\mathrm{C}_{30} \mathrm{H}_{26} \mathrm{~N}_{2} \mathrm{O}_{2}+3 \mathrm{H}^{+}\right]^{+}=449.21$, $\left[\mathrm{C}_{30} \mathrm{H}_{26} \mathrm{FeN}_{2} \mathrm{O}_{2}+\mathrm{H}^{+}\right]^{+}=503.14,\left[\mathrm{C}_{42} \mathrm{H}_{34} \mathrm{FeN}_{4} \mathrm{O}_{2}\right]^{+}=682.21, \mathrm{M} \tau=717.17$. 


\section{Synthesis of [Co(BENZOEN)(1,10-phen $)]$; Complex $\mathbf{3}$}

1,10-Phenanthroline $(0.180 \mathrm{~g}, 0.001 \mathrm{~mol})$ in $10 \mathrm{~mL}$ ethanol was added to a solution of $\mathrm{CoCl}_{2} \cdot 6 \mathrm{H}_{2} \mathrm{O}(0.237 \mathrm{~g}, 0.001 \mathrm{~mol})$ in $15 \mathrm{~mL}$ ethanol and the solution was stirred initially for $15 \mathrm{~min}$. Thereafter, BENZOEN $(0.448 \mathrm{~g}, 0.001 \mathrm{~mol})$ in $25 \mathrm{~mL}$ hot ethanol was added and the resulting reaction mixture was stirred for $1 \mathrm{~h}$ in an inert atmosphere. A dark green precipitate was obtained after refluxing the reaction mixture for $7 \mathrm{~h}$. The precipitate obtained was filtered, washed several times with acetone and recrystallized from hot methanol to yield dark green precipitate. The recrystallized solid was dried in a desiccator over anhydrous calcium chloride under vacuum. Colour $=$ Dark green, Yield: 0.651g $(76.12 \%) ;$ m. p. $>280{ }^{\circ} \mathrm{C}$; Anal. Calc. for $\mathrm{C}_{42} \mathrm{H}_{34} \mathrm{CoN}_{4} \mathrm{O}_{2}(\mathrm{M} \tau=685.20)$ : C, 73.57; H, 5.00; N, 8.17; Co, 8.59. Found: C, 73.50; $\mathrm{H}, 4.89 ; \mathrm{N}, 8.10 ; \mathrm{Co}, 8.44 ; \mu_{\text {eff }}=2.26$ B.M. Molar conductance $\Lambda_{\mathrm{m}}$ at $25^{\circ} \mathrm{C}\left(\Omega^{-1} \mathrm{~cm}^{2} \mathrm{~mol}^{-1}\right): 16$ in DMSO. Selected infrared absorption $\left(\mathrm{KBr}, \mathrm{cm}^{-1}\right): v(\mathrm{C}-\mathrm{H})_{\text {arom }}, 3060(\mathrm{sh}) ; \mathrm{v}(\mathrm{C}=\mathrm{N})_{\text {cyclic }}, 1677(\mathrm{~s})$; $v(\mathrm{C}=\mathrm{N})_{\text {imine }}, 1583(\mathrm{~s}) ; v\left(\mathrm{CH}_{2}-\mathrm{CH}_{2}\right), 920(\mathrm{~m}) ; v(\mathrm{M}-\mathrm{O}), 524(\mathrm{~m}) ; v(\mathrm{M}-\mathrm{N}), 475(\mathrm{~s})$. Electronic spectra $\left(\lambda_{\max }\right.$ in $\mathrm{nm}\left(\varepsilon\right.$ in $\left.\left(\mathrm{mol} \mathrm{L}^{-1} \mathrm{~cm}^{-1}\right)\right)$ in DMF: 540 (21); 340 (1032); 240 (656). ESI-Mass spectra, $m / z:\left[\mathrm{C}_{12} \mathrm{H}_{8} \mathrm{~N}_{2}+\mathrm{H}^{+}\right]^{+}=181.07,\left[\mathrm{C}_{12} \mathrm{H}_{8} \mathrm{CoN}_{2}+\mathrm{H}^{+}\right]^{+}=240.01,\left[\mathrm{C}_{30} \mathrm{H}_{26} \mathrm{~N}_{2} \mathrm{O}_{2}+3 \mathrm{H}^{+}\right]^{+}=449.21$, $\left[\mathrm{C}_{30} \mathrm{H}_{26} \mathrm{CoN}_{2} \mathrm{O}_{2}+\mathrm{H}^{+}\right]^{+}=506.14,\left[\mathrm{C}_{42} \mathrm{H}_{34} \mathrm{CoN}_{4} \mathrm{O}_{2}+\mathrm{H}^{+}\right]^{+}=686.21, \mathrm{M} \tau=685.20$.

\section{Synthesis of [Ni(BENZOEN)(1,10-phen)]; Complex 4}

1,10-Phenanthroline $(0.180 \mathrm{~g}, 0.001 \mathrm{~mol})$ in $10 \mathrm{~mL}$ ethanol was added to a solution containing $\mathrm{NiCl}_{2} \cdot 6 \mathrm{H}_{2} \mathrm{O}(0.237 \mathrm{~g}, 0.001 \mathrm{~mol})$ in $15 \mathrm{~mL}$ ethanol and the solution was stirred initially for $15 \mathrm{~min}$. Thereafter, BENZOEN $(0.448 \mathrm{~g}, 0.001 \mathrm{~mol})$ dissolved in $25 \mathrm{~mL}$ hot ethanol was added and the resulting reaction mixture was stirred for $1 \mathrm{~h}$ in an inert atmosphere. A reddish brown precipitate was obtained after refluxing the reaction mixture for $10 \mathrm{~h}$. The solid obtained was filtered, washed several times with acetone and recrystallized from hot methanol to yield reddish brown crystalline solid. The recrystallized solid was dried in a desiccator over anhydrous calcium chloride under vacuum at room temperature. Colour $=$ Reddish brown, Yield: $0.528 \mathrm{~g}(67.01 \%) ; \mathrm{m} . \mathrm{p} .>280{ }^{\circ} \mathrm{C}$; Anal. Calc. for $\mathrm{C}_{42} \mathrm{H}_{34} \mathrm{NiN}_{4} \mathrm{O}_{2}(\mathrm{M} \tau=684.22): \mathrm{C}, 73.38 ; \mathrm{H}, 5.28 ; \mathrm{N}, 8.15 ; \mathrm{Ni}, 8.54$. Found: $\mathrm{C}, 73.30 ; \mathrm{H}$, 5.25; N, 8.12; Ni, 8.50. $\mu_{\text {eff }}=3.06$ B.M. Molar conductance $\Lambda_{\mathrm{m}}$ at $25^{\circ} \mathrm{C}\left(\Omega^{-1} \mathrm{~cm}^{2} \mathrm{~mol}^{-1}\right): 17$ in DMSO. Selected infrared absorption $\left(\mathrm{KBr}, \mathrm{cm}^{-1}\right): v(\mathrm{C}-\mathrm{H})_{\text {arom }}, 3044(\mathrm{sh}) ; v(\mathrm{C}=\mathrm{N})_{\text {cyclic }}$, 1653(s); $v(\mathrm{C}=\mathrm{N})_{\text {imine }}, 1588(\mathrm{~s}) ; \quad v\left(\mathrm{CH}_{2}-\mathrm{CH}_{2}\right)$, 916(s); $v(\mathrm{M}-\mathrm{O})$, 556(s); $v(\mathrm{M}-\mathrm{N}), 453(\mathrm{~m})$. Electronic spectra $\left(\lambda_{\max }\right.$ in $\mathrm{nm}\left(\varepsilon\right.$ in $\left.\left(\mathrm{mol} \mathrm{L}^{-1} \mathrm{~cm}^{-1}\right)\right)$ in DMF: 560 (76); 440 (50); 340 (312); 260 (244). ESI-Mass spectra, $m / z:\left[\mathrm{C}_{12} \mathrm{H}_{8} \mathrm{~N}_{2}+\mathrm{H}^{+}\right]^{+}=181.07,\left[\mathrm{C}_{12} \mathrm{H}_{8} \mathrm{NiN}_{2}+\mathrm{H}^{+}\right]^{+}=240.00$, $\left[\mathrm{C}_{30} \mathrm{H}_{26} \mathrm{~N}_{2} \mathrm{O}_{2}+3 \mathrm{H}^{+}\right]^{+}=449.21,\left[\mathrm{C}_{30} \mathrm{H}_{26} \mathrm{NiN}_{2} \mathrm{O}_{2}+\mathrm{H}^{+}\right]^{+}=505.14,\left[\mathrm{C}_{42} \mathrm{H}_{36} \mathrm{NiN}_{4} \mathrm{O}_{2}+\mathrm{H}^{+}\right]^{+}=$ 685.45, $\mathrm{M} \tau=684.22$.

\section{DFT Calculation}

The DFT calculations were perform using the Gaussian 09W suite method using B3LYP three parameter density functional theories, which includes Becke's gradient exchange correction, and Lee, Yang, Parr correlation function. The gas phase geometry of BENZOEN and complex 1-4 were fully optimized with respect to the energy using the B3LYP $6-31+g(d, p) / L A N L 2 D Z$ basis set. The charge distribution on the atomic sites was computed using natural bond orbital (NBO) and Mulliken charge. Distribution of electronegative and electropositive atoms over the molecule was presented by the molecular electrostatic potential (MEP) maps. The optimized structural parameters such as bond lengths and bond angles were determined with the atom numbering scheme of the molecule. The electronic properties and quantum chemical properties of all the compounds have been calculated ${ }^{21-24}$. 


\section{Anticorrosion activity}

Anticorrosion activity of BENZOEN and complex 1-4 was done by weight loss measurement method. The mild steel specimens cut into $3 \times 4 \times 0.05 \mathrm{~cm}^{3}$ were abraded successively with different grades of emery paper, washed with distilled water, cleaned with acetone, dried, weighed and kept in a moisture free atmosphere. The corrosive media, $0.5 \mathrm{M}$ of $\mathrm{HCl}$ was prepared by dilution of analytical grade $\mathrm{HCl}$ of predetermined normality with triple distilled water. Anticorrosive solutions were prepared by dissolving $50 \mathrm{ppm}$ of BENZOEN and complex 1-4 in $5 \mathrm{~mL}$ DMSO were added in electrolyte $\mathrm{HCl}$ at room temperature. Immerse the steel specimens in prepared solutions. The specimens were taken out from electrolyte washed and rinsed thoroughly several times with distilled water, cleaned using acetone, dried and reweighed on a digital balance with sensitivity of $0.001 \mathrm{~g}$, after every 6,12 and $24 \mathrm{~h}$. The weight loss was calculated as the difference in weight of the specimen before and after immersion in corrosion media. The corrosion rate (CR) in $\mathrm{mg}$ $\mathrm{cm}^{-2} \mathrm{~h}^{-1}$ was calculated from the following equation:

$$
C R=\frac{\Delta W}{s \times t}
$$

Where, $\Delta \mathrm{W}$ is average weight loss, $\mathrm{s}$ is the total area of the specimen and $\mathrm{t}$ is the immersion time. From the corrosion rate thus obtained, the inhibition efficiency $(\eta \%)$ and surface coverage $(\theta)$ was calculated as follows:

$$
\begin{gathered}
\eta \%=\frac{C R^{o}-C R}{C R^{o}} \times 100 \\
\theta=\frac{\eta \%}{100}
\end{gathered}
$$

Where, $\mathrm{CR}^{\circ}$ and $\mathrm{CR}$ are the corrosion rates of mild steel specimens in the absence and presence of inhibitor respectively ${ }^{25}$.

\section{Biological studies}

\section{Catalase-like activity}

\section{$\mathrm{H}_{2} \mathrm{O}_{2}$ disproportionation reactions and its kinetics}

The catalase-like activity was observed by measuring the volume of $\mathrm{O}_{2}$ produced during the reactions of the ligand/ complex 1-4 with $\mathrm{H}_{2} \mathrm{O}_{2}$ and compared with yeast catalase. The mini reactor is a Kitassato flask $\left(100 \mathrm{~cm}^{3}\right)$ which was magnetically stirred and closed with a rubber septum and connected to a tank filled with water. This was arranged in a manner that the water will be pushed out as oxygen fills the tank. Volume of evolved dioxygen were measured for $14 \mathrm{~min}$ at two minute time intervals. In the first set of experiment, $5 \mathrm{~mL}$ yeast suspension in distilled water was added to the reactor through the septum. Thereafter, $20 \mathrm{~mL}$ aqueous solution of $\mathrm{H}_{2} \mathrm{O}_{2},(8 \mathrm{mmol}, 30 \%)$ was injected into it through the rubber septum with a syringe. Similarly, $20 \mathrm{~mL}$ of $\mathrm{H}_{2} \mathrm{O}_{2}$ was added through the rubber septum with the help of a syringe to the $5 \mathrm{~mL}$ solution of ligand/complex 1-4 in $\mathrm{CH}_{3} \mathrm{CN}$ (1 mmol). The experiment was repeated for highly efficient complex on different concentration. All the experiments were performed at room temperature at $25^{\circ} \mathrm{C}$.

The kinetics study of hydrogen peroxide disproportionation was varied to determine the dependence of the initial rate on the dioxygen evolution. The velocity for catalase-like activity of the complex 1 was obtained by time dependent measurement of decomposition of hydrogen peroxide to water and evolved dioxygen. 


\section{In Vitro antibacterial screening}

Ligand BENZOEN and complex 1-4, were screened for antibacterial activity against gram negative bacteria Escherichia coli, (ATCC no. 35218) at different concentration. Agar well diffusion method was used for antibacterial screening as discussed earlier ${ }^{26}$. In order to observe the activity and confirm the sensitivity, BENZOEN and complex 1-4 were tested for minimum inhibitory concentration (MIC). The most popular method for MIC evaluation, commonly used in clinical laboratory is successive dilution method as discussed earlier ${ }^{27}$.

\section{Results and Discussion}

\section{Characterization of ligand}

Empirical formula of BENZOEN was in agreement with elemental analysis. The ESIMS of BENZOEN (Figure 1) shows peaks at $\mathrm{m} / \mathrm{z}: 225.18 ; 342.16 ; 432.21$ and 449.22 were attributed for $\left[\mathrm{C}_{15} \mathrm{H}_{14} \mathrm{NO}+\mathrm{H}^{+}\right]^{+} ; \quad\left[\mathrm{C}_{23} \mathrm{H}_{21} \mathrm{~N}_{2} \mathrm{O}+\mathrm{H}^{+}\right]^{+} ; \quad\left[\mathrm{C}_{30} \mathrm{H}_{27} \mathrm{~N}_{2} \mathrm{O}+\mathrm{H}^{+}\right]^{+}$and $\left[\mathrm{C}_{30} \mathrm{H}_{28} \mathrm{~N}_{2} \mathrm{O}_{2}+\mathrm{H}^{+}\right]^{+}$respectivily. A peak at 449.22 was attributed to pseudo molecular ion $\left[\mathrm{C}_{30} \mathrm{H}_{28} \mathrm{~N}_{2} \mathrm{O}_{2}+\mathrm{H}^{+}\right]^{+}$.

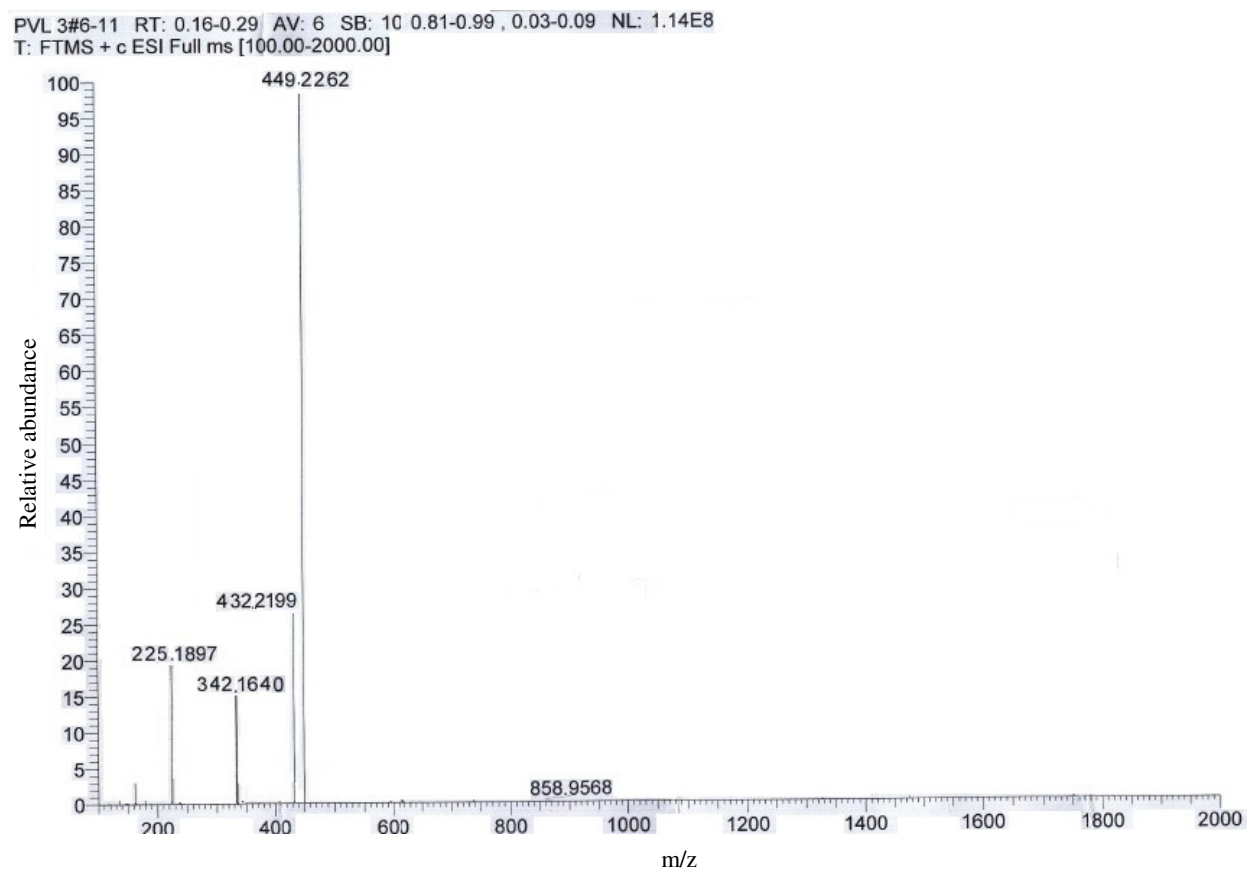

Figure 1. ESI-Mass of ligand BENZOEN

FT-IR spectra of BENZOEN (Figure 2) exhibit a weak band at $3192 \mathrm{~cm}^{-1}$ probably due to hydrogen bonding, attributed to hydroxyl $v(\mathrm{O}-\mathrm{H})$ stretching vibration. A sharp peak at $1604 \mathrm{~cm}^{-1}$ attributed to the stretching vibrations of the $v(>\mathrm{C}=\mathrm{N}-)$ imine group. It also exhibit a signal of sharp intensity at $923 \mathrm{~cm}^{-1}$ attributed for $v\left(\mathrm{CH}_{2}-\mathrm{CH}_{2}\right)^{28}$.

UV-Vis spectra of BENZOEN (Figure 3) exhibit two absorption bands at about $280 \mathrm{~nm}$ and $360 \mathrm{~nm}$. The band of medium intensity at $280 \mathrm{~nm}$ was assigned to the intra-ligand $\pi \rightarrow \pi^{*}$ transition for ( $>\mathrm{C}=\mathrm{N}-$ ) imine nitrogen. The strong band at $360 \mathrm{~nm}$ was attributed to $\mathrm{n} \rightarrow \pi^{*}$ transition associated with aromatic ring. 


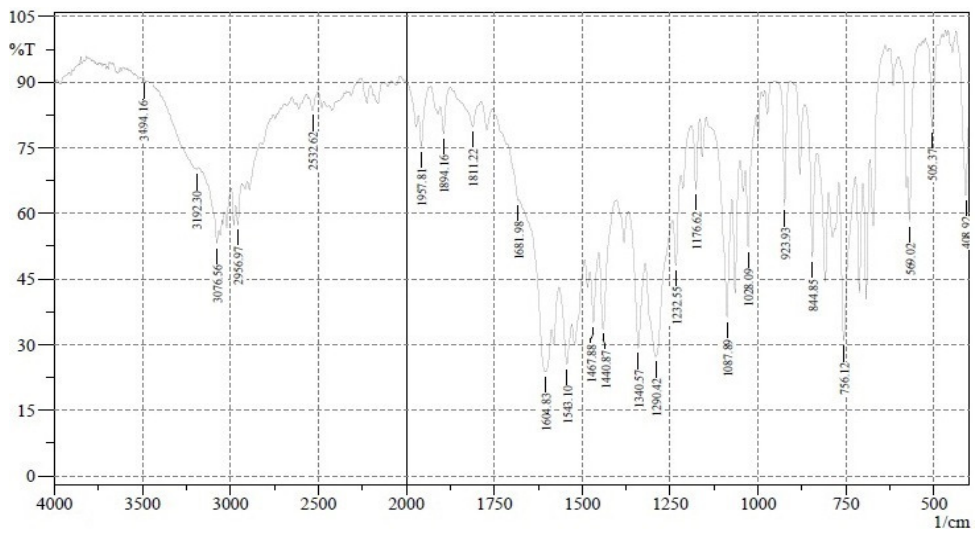

Figure 2. FT-IR spectra of BENZOEN

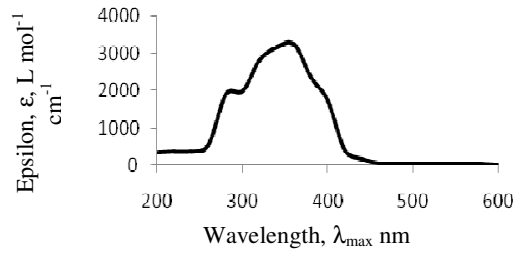

Figure 3. UV-Vis spectra of BENZOEN

${ }^{1}$ H NMR spectra of BENZOEN (Figure 4) displayed seven singlets, two triplet and one doublet in aromatic region. Singlets centered at $\delta 7.980, \delta 7.938, \delta 7.890, \delta 7.800$ and $\delta 7.798 \mathrm{ppm}$ were attributed to $2 \mathrm{H}$ each, respectively. However, singlet at $\delta 7.239$ and $\delta 7.102$ were assigned for $1 \mathrm{H}$ each. Two triplet between $\delta 7.664-7.653$ and 7.004-6.995 ppm were attributed for $6 \mathrm{H}$ with a coupling constant $(\mathrm{J}) 2.8 \mathrm{~Hz}, 1.6 \mathrm{~Hz}, 2.4 \mathrm{~Hz}$ and $1.2 \mathrm{~Hz}$ respectively. One doublet centered at $\delta 7.453 \mathrm{ppm}$ was assigned for $2 \mathrm{H}$. A singlet observed at $\delta 4.03 \mathrm{ppm}$ for four protons was attributed for two methylenic group and another singlet at $\delta 3.40 \mathrm{ppm}$, assigned for two protons of $\mathrm{C}-\mathrm{H}$ moity. A singlet observed at $\delta 12.03 \mathrm{ppm}$ for two protons was assigned for phenolic $(-\mathrm{OH})$ proton.

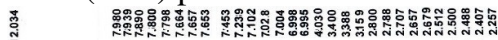

MW

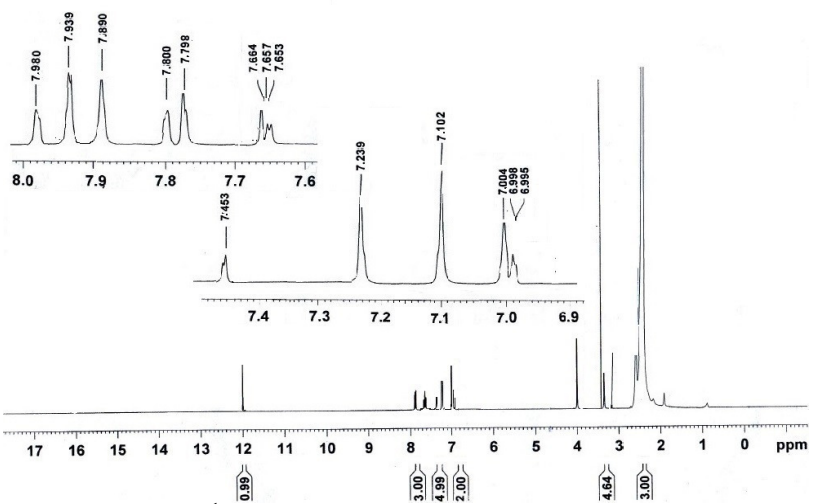

Figure 4. ${ }^{1} \mathrm{H}$ NMR spectra of ligand BENZOEN 
${ }^{13} \mathrm{C}$ NMR spectrum of the BENZOEN (Figure 5) exhibit a signal at $\delta 176.12 \mathrm{ppm}$ assigned for imine ( $>\mathrm{C}=\mathrm{N}-$ ) carbon. The signal appeared at $\delta 165.13 \mathrm{ppm}$ was attributed to the carbon linked with hydroxyl group. All aromatic carbon display signals between $\delta$ 115.91$136.26 \mathrm{ppm}$. The signals observed at $\delta 48.92 \mathrm{ppm}$ was assigned for methylenic carbon ${ }^{29}$.
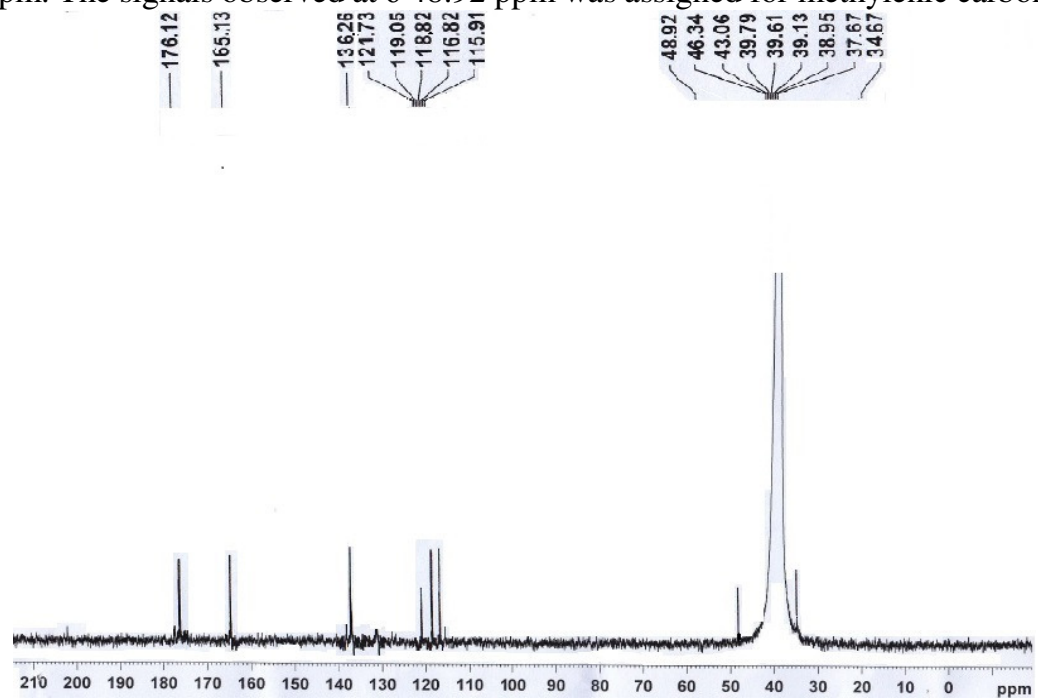

Figure 5. ${ }^{13} \mathrm{C}$ NMR spectra of ligand BENZOEN

Thus, on the basis of the elemental analysis, ESI-MS, UV-Vis, FT-IR, ${ }^{1} \mathrm{H}$ NMR, ${ }^{13} \mathrm{C}$ NMR spectra the probable structure of BENZOEN was suggested in Figure 6.

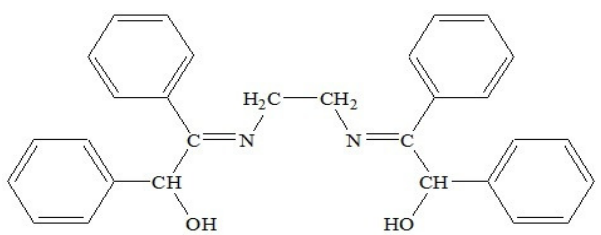

Figure 6. Structure of BENZOEN

\section{Characterization of complexes}

The stoichiometries of the complexes were in agreement with elemental analyses data. Molar conductance of complex 1, 3 and $\mathbf{4}$ was in between $14-17 \Omega^{-1} \mathrm{~cm}^{2} \mathrm{~mol}^{-1}$ indicative of their non ionic nature. However, complex 2 exhibit high molar conductance of $66 \Omega^{-1}$ $\mathrm{cm}^{2} \mathrm{~mol}^{-1}$, suggesting ionic nature as 1:1 electrolytes in DMSO solution ${ }^{30}$. In ESI-MS of complex 1 peaks at $\mathrm{m} / \mathrm{z} 181.06,236.01,449.21,502.14$ and 682.21 attributed for $\left[\mathrm{C}_{12} \mathrm{H}_{8} \mathrm{~N}_{2}+\mathrm{H}^{+}\right]^{+} ; \quad\left[\mathrm{C}_{12} \mathrm{H}_{8} \mathrm{MnN}_{2}+\mathrm{H}^{+}\right]^{+} ; \quad\left[\mathrm{C}_{30} \mathrm{H}_{26} \mathrm{~N}_{2} \mathrm{O}_{2}+3 \mathrm{H}^{+}\right]^{+} ; \quad\left[\mathrm{C}_{30} \mathrm{H}_{26} \mathrm{MnN}_{2} \mathrm{O}_{2}+\mathrm{H}^{+}\right]^{+}$and $\left[\mathrm{C}_{42} \mathrm{H}_{34} \mathrm{MnN}_{4} \mathrm{O}_{2}+\mathrm{H}^{+}\right]^{+}$respectively. The peak at $\mathrm{m} / \mathrm{z} 682.21$ was a pseudomolecular ion peak. In complex 2 peaks were observed at $\mathrm{m} / \mathrm{z}$ 181.07, 237.01, 449.21, 503.14 and 682.21 attributed for $\left[\mathrm{C}_{12} \mathrm{H}_{8} \mathrm{~N}_{2}+\mathrm{H}^{+}\right]^{+} ;\left[\mathrm{C}_{12} \mathrm{H}_{8} \mathrm{FeN}_{2}+\mathrm{H}^{+}\right]^{+} ; \quad\left[\mathrm{C}_{30} \mathrm{H}_{26} \mathrm{~N}_{2} \mathrm{O}_{2}+3 \mathrm{H}^{+}\right]^{+} ;\left[\mathrm{C}_{30} \mathrm{H}_{26} \mathrm{FeN}_{2} \mathrm{O}_{2}+\mathrm{H}^{+}\right]^{+}$ and $\left[\mathrm{C}_{42} \mathrm{H}_{34} \mathrm{FeN}_{4} \mathrm{O}_{2}\right]^{+}$. The peak at $\mathrm{m} / z 682.21$ was molecular ion peak for $\mathrm{M}^{+}$ion due to dissociation of $\mathrm{Cl}^{-}$is confirming 1:1, electrolytic nature of complex 2 .

In complex 3 exhibit several peaks at $\mathrm{m} / z$ 181.07, 240.01, 449.21, 506.14 and 686.21 attributed for $\left[\mathrm{C}_{12} \mathrm{H}_{8} \mathrm{~N}_{2}+\mathrm{H}^{+}\right]^{+} ;\left[\mathrm{C}_{12} \mathrm{H}_{8} \mathrm{CoN}_{2}+\mathrm{H}^{+}\right]^{+} ; \quad\left[\mathrm{C}_{30} \mathrm{H}_{26} \mathrm{~N}_{2} \mathrm{O}_{2}+3 \mathrm{H}^{+}\right]^{+} ;\left[\mathrm{C}_{30} \mathrm{H}_{26} \mathrm{CoN}_{2} \mathrm{O}_{2}+\mathrm{H}^{+}\right]^{+}$ and $\left[\mathrm{C}_{42} \mathrm{H}_{34} \mathrm{CoN}_{4} \mathrm{O}_{2}+\mathrm{H}^{+}\right]^{+}$. The peak at 686.21 was due to pseudomolecular ion. 
Complex 4 shows peak at, $m / z$ 181.07, 240.00, 449.21, 505.14 and 687.45 attributed for $\left[\mathrm{C}_{12} \mathrm{H}_{8} \mathrm{~N}_{2}+\mathrm{H}^{+}\right]^{+} ; \quad\left[\mathrm{C}_{12} \mathrm{H}_{8} \mathrm{NiN}_{2}+\mathrm{H}^{+}\right]^{+} ; \quad\left[\mathrm{C}_{30} \mathrm{H}_{26} \mathrm{~N}_{2} \mathrm{O}_{2}+3 \mathrm{H}^{+}\right]^{+} ; \quad\left[\mathrm{C}_{30} \mathrm{H}_{26} \mathrm{NiN}_{2} \mathrm{O}_{2}+\mathrm{H}^{+}\right]^{+}$and $\left[\mathrm{C}_{42} \mathrm{H}_{34} \mathrm{NiN}_{4} \mathrm{O}_{2}+\mathrm{H}^{+}\right]^{+}$. The peak at $\mathrm{m} / z 687.45$ was due to pseudomolecular ion. ESI-MS of complex $\mathbf{1}$ is shown in Figure 7.

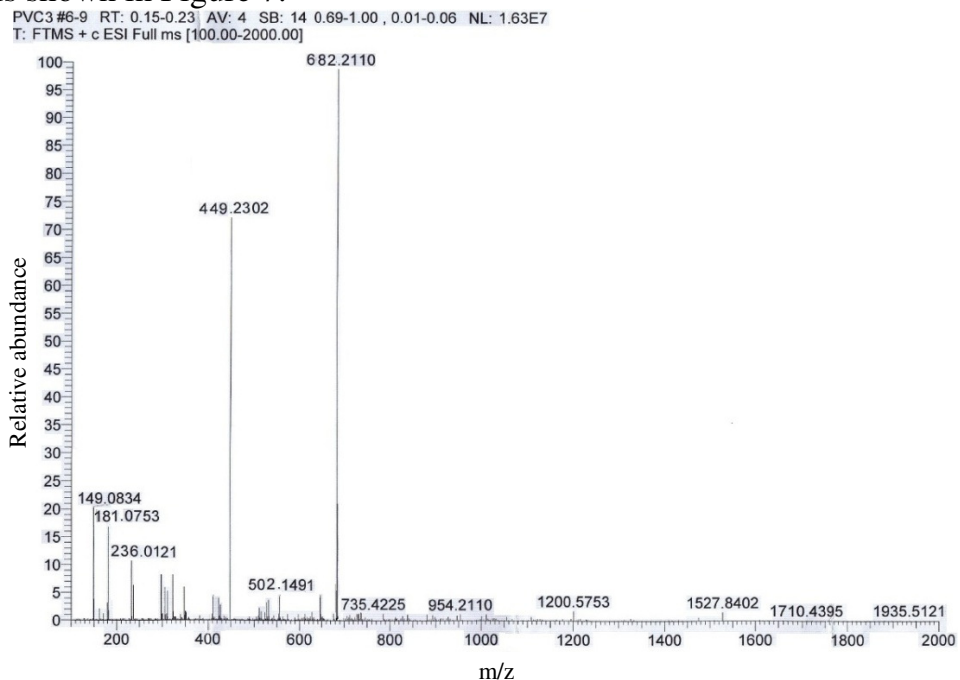

Figure 7. ESI-MS spectra of complex 1

In FT-IR spectra of complex 1-4, a new peak observed in between $1645-1699 \mathrm{~cm}^{-1}$ was attributed to cyclic $v(\mathrm{C}=\mathrm{N})$ moiety of phenanthroline. A strong peak appeared at $1604 \mathrm{~cm}^{-1}$ in BENZOEN for imine $v(>\mathrm{C}=\mathrm{N}-)$ group was shifted downwards in the complexes and observed in between 1583-1589 $\mathrm{cm}^{-1}$ indicating the coordination of imine nitrogen to the metal. This was supported by the appearance of new sharp signals between $443-475 \mathrm{~cm}^{-1}$ in the complexes due to M-N coordination. A sharp peak appeared at $3192 \mathrm{~cm}^{-1}$ in BENZOEN assigned to O-H stretching was vanished completely in the complexes and a new peak was appeared in between 524-569 $\mathrm{cm}^{-1}$ was assigned to M-O stretching indicative of the bonding of metal to the oxygen by removal ${ }^{13}$ of phenolic-H. Complexes also exhibit sharp signals between $887-932 \mathrm{~cm}^{-1}$ attributed to $v\left(\mathrm{CH}_{2}-\mathrm{CH}_{2}\right)$ group. FT-IR spectra of complex $\mathbf{1}$ is given in Figure 8.

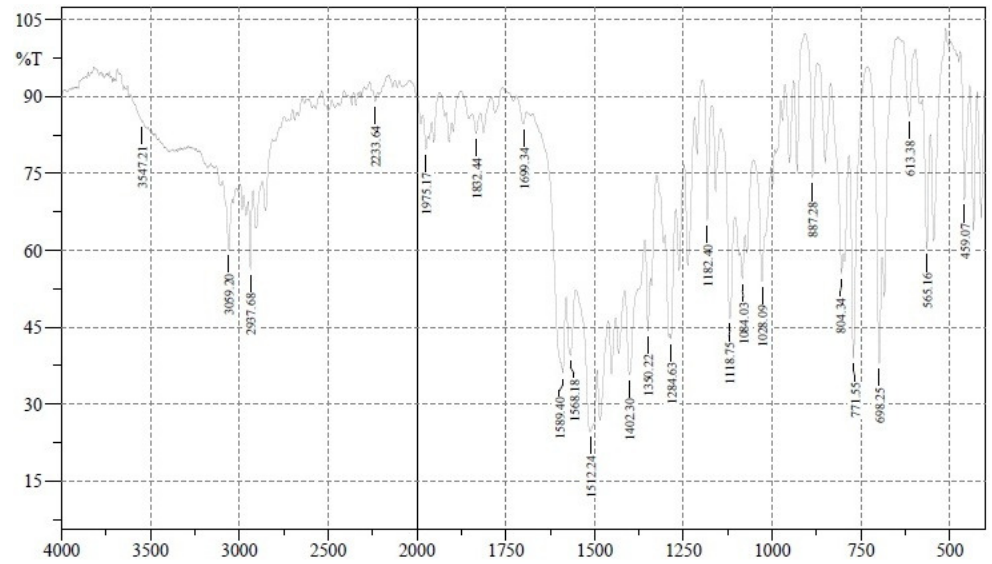

Figure 8. FT-IR spectra of complex 1 
The free ligand exhibited two strong absorptions bands at 280 and $360 \mathrm{~nm}$ which was due $\pi \rightarrow \pi^{*}$ and $\mathrm{n} \rightarrow \pi^{*}$ transitions. In complexes absorption band in the range between 240-260 nm and 320-440 nm were attributed to $\pi \rightarrow \pi^{*}$ and $\mathrm{n} \rightarrow \pi^{*}$ transition associated with $(>C=N-)$ imine nitrogen and intra ligand charge transfer respectively. The bathochromic shift of this absorption upon complexation was due to the donation of a lone pair of electrons to the metal ion, indicating the coordination of imine nitrogen. These transitions were shifted to higher or lower frequencies may be due to the ligand to metal and metal to ligand charge transfer ${ }^{31}$.

Complex 1 exhibits magnetic moment of $2.45 \mathrm{~B}$. M. which indicate that complex was low spin with one unpaired electron in $\mathrm{Mn}(\mathrm{II})$ probably due to presence of a strong field ligand 1, 10-phenanthroline. The complex 1 exhibit (Figure 9) three absorption bands at 740, 640 and 540 nm attributed to ${ }^{6} \mathrm{~A}_{1 \mathrm{~g}} \rightarrow{ }^{4} \mathrm{~T}_{1 \mathrm{~g}}\left(v_{1}\right),{ }^{6} \mathrm{~A}_{1 \mathrm{~g}} \rightarrow{ }^{4} \mathrm{~T}_{2 \mathrm{~g}}\left(v_{2}\right)$ and ${ }^{6} \mathrm{~A}_{1 \mathrm{~g}} \rightarrow{ }^{4} \mathrm{E}_{\mathrm{g}},{ }^{4} \mathrm{~A}_{1 \mathrm{~g}}\left(v_{3}\right)$ transitions respectively, indicating distorted octahedral geometry around $\mathrm{Mn}$ (II) ion. Complex 2 exhibits magnetic moment of 2.81 B.M. which is lower than the expected value of the high spin octahedral arrangement, suggesting an antiferromagnetic interaction. The electronic spectra shows bands at $540 \mathrm{~nm}$ indicates an octahedral geometry around the metal ion and $460 \mathrm{~nm}$ due to charge transfer. However, it was not possible to identify the type of the d-d transition. The magnetic moment of complex 3 was 2.26 B.M. corresponding to one unpaired electrons in Co(II). The electronic spectrum of this complex exhibit a band at $540 \mathrm{~nm}, 740 \mathrm{~nm}$ and $780 \mathrm{~nm}$ which may be assigned to the ${ }^{4} \mathrm{~T}_{1 \mathrm{~g}}(\mathrm{~F}) \rightarrow{ }^{4} \mathrm{~T}_{1 \mathrm{~g}}(\mathrm{P})\left(v_{3}\right),{ }^{4} \mathrm{~T}_{1 \mathrm{~g}}(\mathrm{~F}) \rightarrow{ }^{4} \mathrm{~A}_{2 \mathrm{~g}}(\mathrm{~F})\left(v_{2}\right)$ and ${ }^{4} \mathrm{~T}_{1 \mathrm{~g}}(\mathrm{~F}) \rightarrow{ }^{4} \mathrm{~T}_{2 \mathrm{~g}}(\mathrm{~F})\left(v_{1}\right)$ transition confirming an octahedral geometry. Complex 4 exhibit magnetic susceptibility of $3.06 \mathrm{~B}$. M., indicating the presence of two unpaired electrons in $\mathrm{Ni}$ (II) ion consistent with octahedral geometry with antiferromagnetic interactions. The electronic spectrum of complex $\mathbf{4}$ displayed two bands at $440 \mathrm{~nm}$ and $560 \mathrm{~nm}$ assigned for ${ }^{3} \mathrm{~A}_{1 \mathrm{~g}} \rightarrow{ }^{3} \mathrm{~T}_{1 \mathrm{~g}}(\mathrm{P})\left(\mathrm{v}_{3}\right)$ and ${ }^{3} \mathrm{~A}_{2 \mathrm{~g}} \rightarrow{ }^{3} \mathrm{~T}_{1 \mathrm{~g}}(\mathrm{~F})\left(\mathrm{v}_{2}\right) \mathrm{d}-\mathrm{d}$ transitions indicative of $\mathrm{Ni}(\mathrm{II})$ ion in an octahedral environment ${ }^{32-34}$.

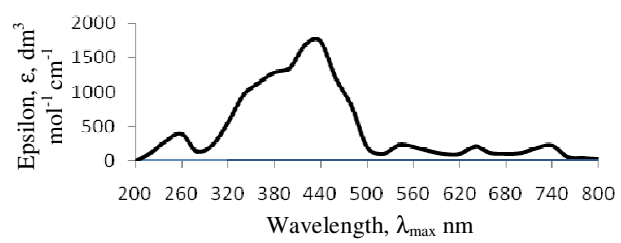

Figure 9. UV-Vis spectra spectra of complex 1

\section{Quantum chemical calculations}

\section{Geometry optimization}

Determination of the molecular structure of complexes in the absence of single crystal structure, geometry optimization is the first and foremost computational step that is run to get energy minimal state of a compound. The BENZOEN and complex 1 geometrically optimized and the results have furnished the total energy E (RB3LYP) equal to -1412.02 a.u. and -2093.72 a.u. respectively. The different geometrical parameters viz., bond lengths, bond angles and dihedral angles were obtained and shown in Table 1-3. The important bond lengths of BENZOEN such as $\mathrm{C}=\mathrm{N}$ (imine), $\mathrm{C}-\mathrm{O}$ (phenolic), $\mathrm{C}-\mathrm{C}$ (connected with imine $\mathrm{C}$ ) and $\mathrm{C}-\mathrm{N}$ (connected with imine $\mathrm{N}$ ) become slightly longer in complexes as BENZOEN coordinates via imine nitrogen and phenolic oxygen of ligand. By the shifting of electron density of imine nitrogen to metal, M-N bond was formed. The O-H (hydroxyl) bond is vanished in complexes and also $\mathrm{C}-\mathrm{O}$ bond distance becomes longer due to the formation of $\mathrm{M}-\mathrm{O}$ bond which make the $\mathrm{C}-\mathrm{O}$ bond longer. This elongation in $\mathrm{M}-\mathrm{N}$ and $\mathrm{M}-\mathrm{O}$ bond lengths caused a slight distortion from the regular octahedral geometries. Additionally, the $N, N^{\prime}$-bidentate coordination of phenanthroline in all complexes forms another five membered metallocycle. 
Similarly, computed bond angles in connection with the metallic binding sphere of the complex, such as $\mathrm{C}-\mathrm{C}-\mathrm{O}, \mathrm{C}-\mathrm{N}=\mathrm{C}_{\text {imine }}$ and $\mathrm{C}-\mathrm{N}-\mathrm{C}_{\text {phen }}$ angles. The bond angles distortions were observed in the coordination sphere of the complex, such as cis $\mathrm{N}_{\text {phen }}-\mathrm{M}-\mathrm{N}_{\text {imine }}, \mathrm{N}_{\text {phen }}{ }^{-}$ $\mathrm{M}-\mathrm{O}$ and $\mathrm{N}_{\text {imine }}-\mathrm{M}-\mathrm{O}$ are smaller than trans $\mathrm{N}_{\text {phen }}-\mathrm{M}-\mathrm{N}_{\text {imine }}, \mathrm{N}_{\text {phen }}-\mathrm{M}-\mathrm{O}$ and $\mathrm{N}_{\text {imine }}-\mathrm{M}-\mathrm{O}$ suggest the octahedral geometry for the complex under discussion ${ }^{35,36}$.

\section{Quantum chemical parameters}

The calculated values of the following quantum chemical parameters: the highest occupied molecular orbital energy $\left(E_{\text {НОмO }}\right)$, the lowest unoccupied molecular orbital energy $\left(E_{L U M O}\right)$, the difference between HOMO and LUMO energy levels $(\Delta E)$, Mulliken electronegativity $(\chi)$, absolute hardness $(\eta)$, absolute softness $(\sigma)$, chemical potential $(P i)$, global softness $(S)$, global electrophilicity $(\omega)$, additional electronic charge $\left(\Delta N_{\max }\right)$, dipole moment $(\mu)$ and total energy $\mathrm{E}$ (RB3LYP) after geometrical optimization of the structures of compounds were listed in Table 4.

Table 1. Selected geometrical bond lengths (in $\AA$ ) of BENZOEN and complexes 1

\begin{tabular}{|c|c|c|c|}
\hline S. No. & Bond connectivity & BENZOEN & Complex 1 \\
\hline 1. & $\mathrm{C}-\mathrm{O}$ & (C12-O14) 1.4298 & $(\mathrm{C} 1-\mathrm{O} 3) 1.4378$ \\
\hline 2. & $\mathrm{C}-\mathrm{O}^{\prime}$ & (C47-O60) 1.4300 & (C60-O36) 1.4465 \\
\hline 3. & $\mathrm{H}-\mathrm{O}$ & $(\mathrm{H} 6-\mathrm{O} 14) 0.9598$ & - \\
\hline 4. & $\mathrm{H}-\mathrm{O}^{\prime}$ & (H62-O60) 0.9600 & - \\
\hline 5. & $\mathrm{C}=\mathrm{N}$ (imine) & $(\mathrm{C} 15=\mathrm{N} 27) 1.2930$ & $(\mathrm{C} 4=\mathrm{N} 16) 1.3123$ \\
\hline 6. & $\mathrm{C}=\mathrm{N}^{\prime}$ (imine) & $(\mathrm{C} 35=\mathrm{N} 34) 1.2935$ & $(\mathrm{C} 24=\mathrm{N} 23) 1.3077$ \\
\hline 7. & $\mathrm{C}-\mathrm{C}($ close to imine $\mathrm{C})$ & $(\mathrm{C} 15-\mathrm{C} 16) 1.5407$ & (C4-C5) 1.5412 \\
\hline 8. & $\mathrm{C}-\mathrm{C}^{\prime}($ close to imine $\mathrm{C})$ & (C41-C35) 1.5409 & (C24-C30) 1.5415 \\
\hline 9. & $\mathrm{Mn}-\mathrm{O}$ & - & $(\mathrm{Mn}-\mathrm{O} 3) 1.8571$ \\
\hline 10. & $\mathrm{Mn}-\mathrm{O}^{\prime}$ & - & (Mn-O36) 1.8554 \\
\hline 11. & Mn-N (imine) & - & (Mn-N16) 1.8979 \\
\hline 12. & Mn-N' (imine) & - & $(\mathrm{Mn}-\mathrm{N} 23) 1.8960$ \\
\hline 13. & Mn-N (phen) & - & (Mn-N58) 1.8931 \\
\hline 14. & Mn-N' (phen) & - & (Mn-N59) 1.8939 \\
\hline
\end{tabular}

Table 2. Selected geometrical bond angles of BENZOEN and complex 1

\begin{tabular}{|c|c|c|c|}
\hline \multicolumn{2}{|c|}{ S. No. Geometrical bond angles } & BENZOEN & Complex 1 \\
\hline 1. & $\angle \mathrm{C}-\mathrm{C}-\mathrm{O}$ & $(\angle \mathrm{C} 3-\mathrm{C} 12-\mathrm{O} 14) 109.470$ & $(\angle \mathrm{C} 3-\mathrm{C} 1-\mathrm{O} 3) 105.266$ \\
\hline 2. & $\angle \mathrm{C}-\mathrm{C}-\mathrm{O}^{\prime}$ & $(\angle \mathrm{C} 52-\mathrm{C} 47-\mathrm{O} 60) 109.469$ & $(\angle \mathrm{C} 24-\mathrm{C} 60-\mathrm{O} 36) 104.614$ \\
\hline 3. & $\angle \mathrm{C}-\mathrm{N}-\mathrm{C}$ (imine) & $(\angle \mathrm{C} 15-\mathrm{N} 27-\mathrm{C} 28) 120.013$ & $(\angle \mathrm{C} 4-\mathrm{N} 16-\mathrm{C} 17) 125.741$ \\
\hline 4. & $\angle \mathrm{C}-\mathrm{N}^{\prime}-\mathrm{C}$ (imine) & $(\angle \mathrm{C} 29-\mathrm{N} 34-\mathrm{C} 35) 120.011$ & $(\angle \mathrm{C} 47-\mathrm{N} 23-\mathrm{C} 18) 127.0556$ \\
\hline 5. & $\angle \mathrm{H}-\mathrm{O}-\mathrm{C}$ & $(\angle \mathrm{H} 61-\mathrm{O} 14-\mathrm{C} 12) 109.469$ & - \\
\hline 6. & $\angle \mathrm{H}-\mathrm{O}^{\prime}-\mathrm{C}$ & $(\angle \mathrm{H} 62-\mathrm{O} 60-\mathrm{C} 47) 109.470$ & - \\
\hline 7. & $\angle \mathrm{C}-\mathrm{N}-\mathrm{C}$ (phen) & - & $(\angle \mathrm{C} 41-\mathrm{N} 58-\mathrm{C} 42) 120.427$ \\
\hline 8. & $\angle \mathrm{C}-\mathrm{N}^{\prime}-\mathrm{C}($ phen $)$ & - & $(\angle \mathrm{C} 44-\mathrm{N} 59-\mathrm{C} 50) 120.452$ \\
\hline \multicolumn{4}{|r|}{ (2) } \\
\hline 9. & $\angle \mathrm{N}($ phen $)-\mathrm{M}-\mathrm{N}($ imine $)$ & - & $(\angle \mathrm{N} 16-\mathrm{Mn}-\mathrm{N} 58) 82.683$ \\
\hline 10. & $\angle \mathrm{N}($ phen $)-\mathrm{M}-\mathrm{O}$ & - & $(\angle \mathrm{N} 58-\mathrm{Mn}-\mathrm{O} 36) 102.358$ \\
\hline 11. & $\angle \mathrm{N}$ (imine)-M-O & - & $(\angle \mathrm{N} 16-\mathrm{Mn}-\mathrm{O} 3) 80.990$ \\
\hline \multicolumn{4}{|l|}{ Trans } \\
\hline 12. & $\angle \mathrm{N}^{\prime}($ phen $)-\mathrm{M}-\mathrm{N}^{\prime}($ imine $)$ & - & $(\angle \mathrm{N} 23-\mathrm{Mn}-\mathrm{N} 59) 111.335$ \\
\hline 13. & $\angle \mathrm{N}^{\prime}$ (phen)-M-O' & - & $(\angle \mathrm{N} 59-\mathrm{Mn}-\mathrm{O} 36) 79.735$ \\
\hline 14. & $\angle \mathrm{N}^{\prime}$ (imine)-M-O & - & $(\angle \mathrm{N} 23-\mathrm{Mn}-\mathrm{O} 36) 78.829$ \\
\hline
\end{tabular}


Table 3. Selected dihedral bond angles of BENZOEN and complex 1

\begin{tabular}{cccc}
\hline $\begin{array}{c}\text { S. } \\
\text { No. }\end{array}$ & $\begin{array}{c}\text { Dihedral } \\
\text { bond angles }\end{array}$ & BENZOEN & Complex 1 \\
\hline 1. & $\angle \mathrm{C}-\mathrm{C}-\mathrm{N}-\mathrm{C}$ & $(\angle \mathrm{C} 16-\mathrm{C} 15-\mathrm{N} 27-\mathrm{C} 28)-0.0459$ & $(\angle \mathrm{C} 5-\mathrm{C} 4-\mathrm{N} 16-\mathrm{C} 17) 1.0126$ \\
2. & $\angle \mathrm{C}-\mathrm{C}-\mathrm{N}^{\prime}-\mathrm{C}$ & $(\angle \mathrm{C} 41-\mathrm{C} 35-\mathrm{N} 27-\mathrm{C} 28) 179.955$ & $(\angle \mathrm{C} 30-\mathrm{C} 24-\mathrm{N} 23-\mathrm{C} 18)-8.814$ \\
3. & $\angle \mathrm{N}-\mathrm{C}-\mathrm{N}^{\prime}-\mathrm{C}$ & $(\angle \mathrm{N} 27-\mathrm{C} 28-\mathrm{C} 31-\mathrm{N} 34)-125.257$ & $(\angle \mathrm{N} 16-\mathrm{C} 17-\mathrm{C} 18-\mathrm{N} 23)-41.768$ \\
4. & $\angle \mathrm{N}-\mathrm{C}-\mathrm{O}-\mathrm{C}$ & $(\angle \mathrm{N} 34-\mathrm{C} 35-\mathrm{C} 47-\mathrm{O} 60)-30.017$ & $(\angle \mathrm{N} 16-\mathrm{C} 4-\mathrm{C} 1-\mathrm{O} 3) 28.219$ \\
5. & $\angle \mathrm{N}^{\prime}-\mathrm{C}-\mathrm{O}^{\prime}-\mathrm{C}$ & $(\angle \mathrm{N} 27-\mathrm{C} 15-\mathrm{C} 12-\mathrm{O} 14) 29.999$ & $(\angle \mathrm{N} 23-\mathrm{C} 24-\mathrm{C} 60-\mathrm{O} 36)-25.986$ \\
6. & $\angle \mathrm{C}-\mathrm{N}^{\prime}-\mathrm{Mn}-\mathrm{N}$ & - & $(\angle \mathrm{C} 24-\mathrm{N} 23-\mathrm{Mn} 37-\mathrm{N} 16) 155.186$ \\
7. & $\angle \mathrm{C}-\mathrm{N}-\mathrm{Mn}-\mathrm{N}^{\prime}$ & - & $(\angle \mathrm{C} 4-\mathrm{N} 16-\mathrm{Mn} 37-\mathrm{N} 23) 175.400$ \\
8. & $\angle \mathrm{C}-\mathrm{N}-\mathrm{Mn}-\mathrm{O}$ & - & $(\angle \mathrm{C} 4-\mathrm{N} 16-\mathrm{Mn} 37-\mathrm{O} 3)-22.437$ \\
9. & $\angle \mathrm{C}-\mathrm{N}^{\prime}-\mathrm{Mn}-\mathrm{O}^{\prime}$ & - & $(\angle \mathrm{C} 24-\mathrm{N} 23-\mathrm{Mn} 37-\mathrm{O} 36) 31.314$ \\
10. & $\angle \mathrm{C}-\mathrm{N}-\mathrm{Mn}-\mathrm{N}$ & - & $(\angle \mathrm{C} 4-\mathrm{N} 16-\mathrm{Mn} 37)-\mathrm{N} 58) 81.379$ \\
11. & $\angle \mathrm{C}-\mathrm{N}^{\prime}-\mathrm{Mn}-\mathrm{N}^{\prime}$ & - & $(\angle \mathrm{C} 24-\mathrm{N} 23-\mathrm{Mn} 37-\mathrm{N} 59)-42.892$ \\
12. & $\angle \mathrm{N}^{\prime}-\mathrm{N}-\mathrm{O}-\mathrm{Mn}$ & - & $(\angle \mathrm{N} 16-\mathrm{N} 58-\mathrm{O} 3-\mathrm{Mn} 37)-79.066$ \\
13. & $\angle \mathrm{N}^{\prime}-\mathrm{N}^{\prime}-\mathrm{O}^{\prime}-\mathrm{Mn}$ & - & $(\angle \mathrm{N} 23-\mathrm{N} 59-\mathrm{O} 36-\mathrm{Mn} 37)-114.371$ \\
\hline
\end{tabular}

Table 4. The calculated quantum chemical parameters of BENZOEN and complex 1

\begin{tabular}{|c|c|c|c|c|c|c|c|c|c|c|c|c|}
\hline 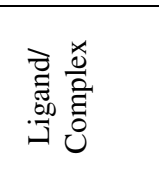 & 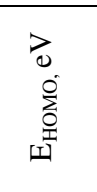 & $\begin{array}{l}> \\
0 \\
0 \\
\vdots \\
5 \\
4\end{array}$ & $\begin{array}{l}\overrightarrow{0} \\
\text { w্ }\end{array}$ & $\begin{array}{l}> \\
x \\
x\end{array}$ & $\begin{array}{l}\overrightarrow{0} \\
=\end{array}$ & $\begin{array}{l}\overrightarrow{3} \\
0 \\
0\end{array}$ & i & $\begin{array}{l}\overline{3} \\
\text { id } \\
\text { is }\end{array}$ & $\begin{array}{l}\overrightarrow{0} \\
\dot{3}\end{array}$ & 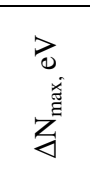 & 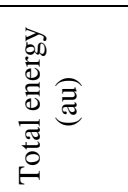 & 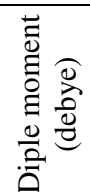 \\
\hline BENZOEN & -6.158 & -1.590 & 4.568 & 3.874 & 2.284 & 0.437 & -3.874 & 0.218 & 3.285 & 1.696 & -1412.02 & 6.42 \\
\hline $\begin{array}{c}\text { Complex } 1 \\
(\alpha)\end{array}$ & -2.913 & -1.701 & 1.211 & 2.307 & 0.605 & 1.651 & -2.307 & 0.825 & 4.396 & 3.810 & -2093.72 & 2.611 \\
\hline $\begin{array}{c}\text { Complex } 1 \\
(\beta)\end{array}$ & -3.555 & -1.736 & 1.818 & 2.645 & 0.909 & 1.099 & -2.645 & 0.549 & 3.848 & 2.909 & & \\
\hline
\end{tabular}

HOMO and LUMO are two significant parameters derived from molecular orbital approach, which have been found applicable to explain properties of a compound ${ }^{37}$. The energy gap between these two orbital, also called band gap $(\Delta E)$, was used to establish chemical stability and reactivity of a molecule ${ }^{38}$. In the compounds under investigation, some important molecular orbital for the BENZOEN and the complex 1 were selected to explain the difference that occurred to the various energy characters of BENZOEN when bonded with metal. BENZOEN coordinates to metal ions through the nitrogen of imine, deprotonated oxygen of the hydroxyl group and the two nitrogens of phenanthroline moiety. These atoms carry more charge confirming active sites for coordination. The energy difference between values of absolute softness $(\sigma)$ in BENZOEN and complex 1 indicates that BENZOEN has a good tendency to chelate with metal ions. The negative values of chemical potential $(\mathrm{Pi})$ in complex 1 indicate that energy must decrease upon accepting electronic charge form BENZOEN. The value of $P i$ depends upon the Mulliken electronegativity $(\chi)$. The increase in the global electrophilicity $(\omega)$ value of complex 1 attributed to higher electron accepting capability.

\section{Charge population analysis and electron density plots}

Natural charge population analyses of Natural bond orbital (NBO) and Mulliken population analysis are the two well-known scales generally used to find the charge analysis within a molecule. The natural atomic charges under both these scales of the representative BENZOEN 
and complex 1 are compared in Table 5, Although the fact that Mulliken scale is not so much reliable in such analysis, the results give a surprising difference between the Mulliken's and the NBO charges, The observed data given in the Table 5 shows that the central metal atom $\mathrm{Mn}$, two carbon atoms $\mathrm{C} 15, \mathrm{C} 35$ and all the hydrogen atoms are positively charged both in NBO and Mulliken analyses. But, some carbon atoms such as C3, C16, C17, C18, C41, C52 and $\mathrm{C} 53$ bears positive charge in Mulliken analysis while negative charge in other scale and two carbon atoms $\mathrm{C} 12$ and C47 are negatively charged in Mulliken analysis but positively charged in NBO analysis. All the remaining carbon atoms and some electronegative atoms such as N27, N34, O14 and O16 bear negative charges over them in both types of evaluation. These results can be clearly seen in the graphical representation of NBO and Mulliken charges of complex given in Figure 10 and 11. As natural bond orbital are linear combinations of the natural atomic orbital's (NAO's) of two bonded atoms, the natural population analysis comes into play in consideration with Pauli's exclusion principle and solves the basis set dependence problem of the Mulliken population analysis ${ }^{39,40}$.

Table 5. Selected Mulliken atomic charges and NBO partial charges of BENZOEN and complex 1

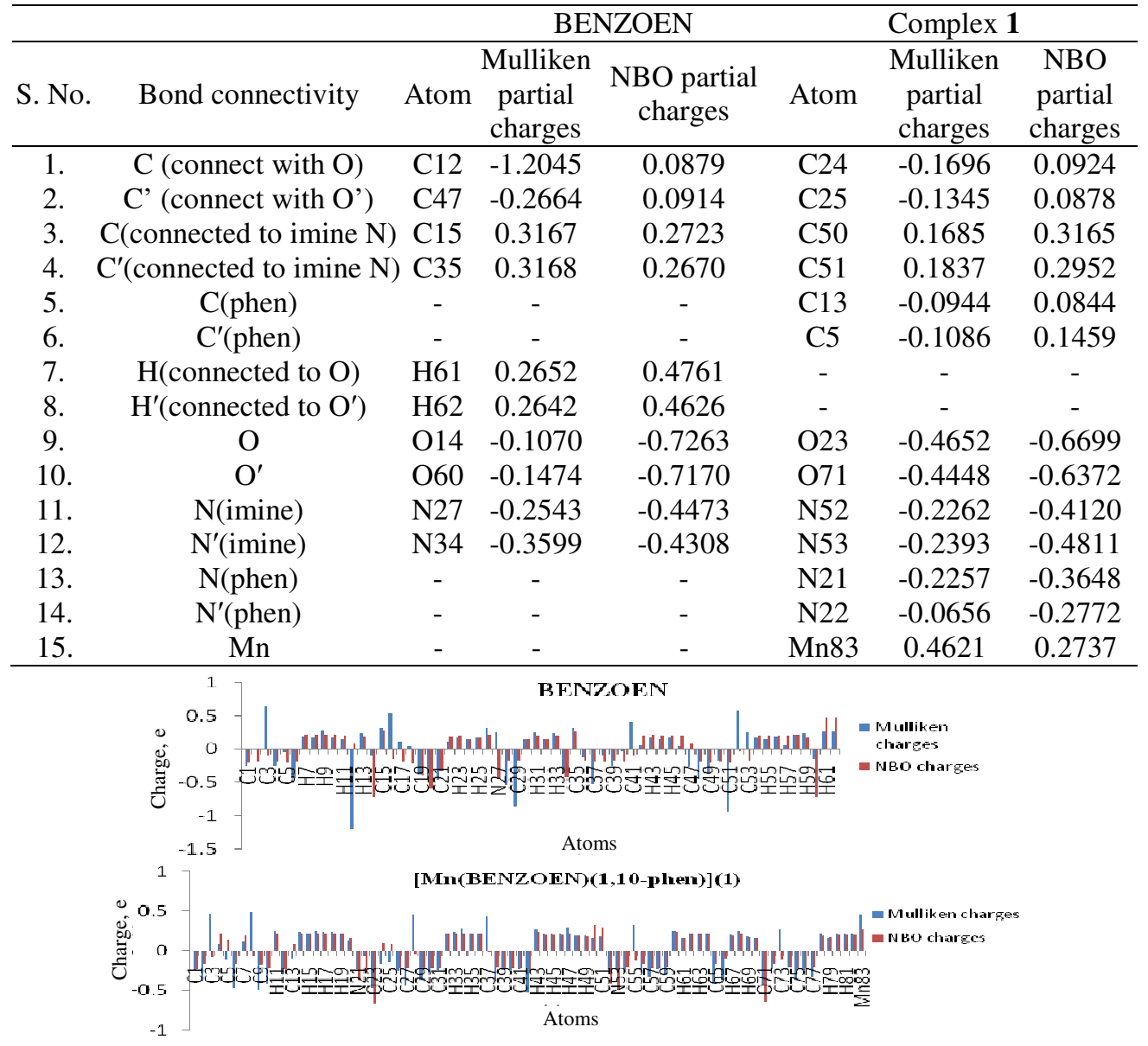

Figure 10. Graphical representation of atomic charges of BENZOEN and complex 1 

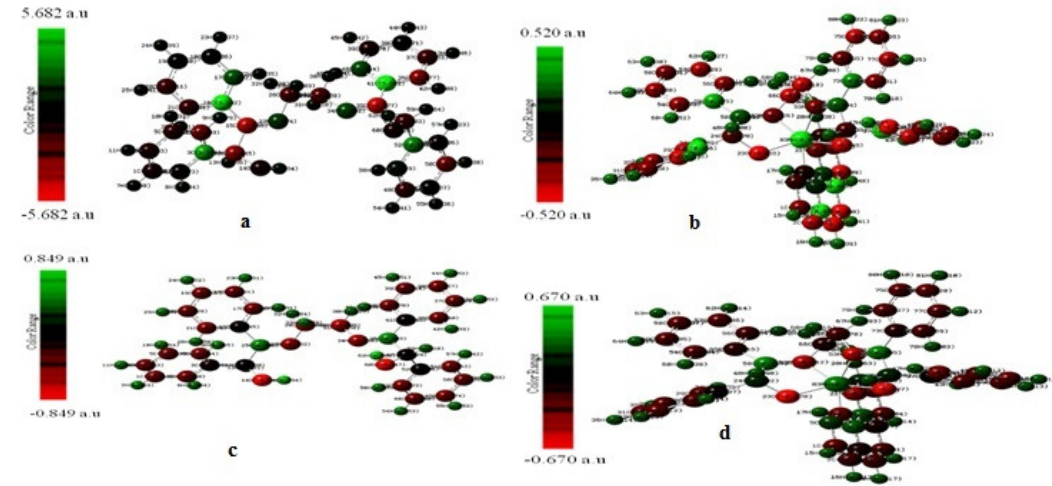

Figure 11. Mulliken atomic charges of (a) BENZOEN, (b) complex 1, (c) NBO atomic charges of BENZOEN and (d) complex 1

\section{Molecular electrostatic potential analysis (MEP) and contour maps}

A well-remarked molecular electrostatic surface potential (MESP) charge regionalization is set up with the help of electron density plot. In that, nucleophilic centers (negative regions), electrophilic sites (positive regions) and neutral loci are pointed out. The potential surface diagrams of ligand and its complex as shown in Figure 12 displays these electrostatic potential values for the representative compounds under study. MEP of BENZOEN and complex 1 indicates that the hydroxyl oxygen atoms represent the most negative potential region, while referring to the charge density plot of the complex, the coordination sphere of complex 1 two oxygen atoms and four nitrogen atoms bears the most negative potential. The hydrogen atoms bears the region of maximum positive charge (blue) in case of BENZOEN and manganese bear positive charge in the case of complex 1 . The green region in the MESP surfaces represents neutral potential between the two extremes red and dark blue color ${ }^{41}$.

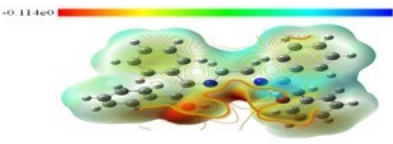

A

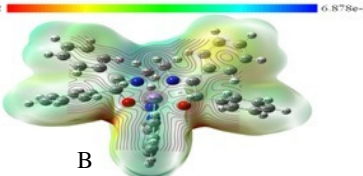

Figure 12. (a) Molecular Electrostatic Potential (MEP) of BENZOEN and (b) Molecular Electrostatic Potential (MEP) of complex 1
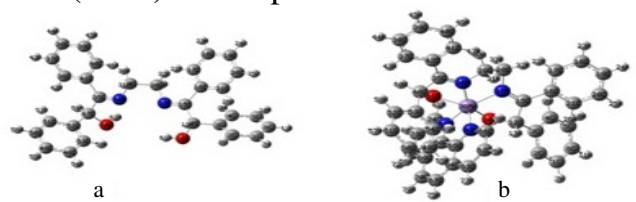

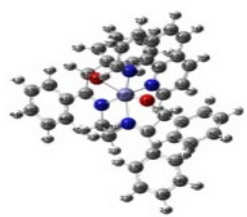

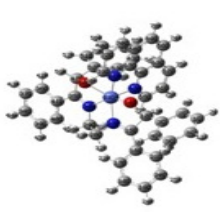

$\mathrm{d}$

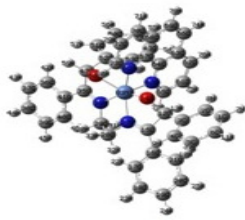

e

Figure 13. DFT optimized structure of (a) BENZOEN, (b) complex 1, (c) complex 2, (d) complex 3, (e) complex 4 
Thus, on the basis of the elemental analysis, ESI-MS, molar conductance, magnetic suceptibility, electronic spectra, FT-IR, ${ }^{1} \mathrm{H}$ NMR, ${ }^{13} \mathrm{C}$ NMR and DFT studies, probable structure of the BENZOEN and complex 1-4 were suggested as below in Figure 13(a-e).

\section{Corrosion inhibition efficiency}

\section{Weight loss measurement}

Corrosion inhibition study of ligand BENZOEN and complexes 1-4 was performed by using weight loss measurement method. The concentration of the ligand BENZOEN and their complexes 1-4 were chosen to be $50 \mathrm{ppm}$. It was observed that ligand BENZOEN exhibits better inhibition efficiency than complex 1-4. This difference in inhibition efficiency was because of the presence of $\mathrm{N}$ and $\mathrm{O}$ atom in BENZOEN which increases electron density to greater extent as compared to complexes. The results shows that better adsorption of BENZOEN and complex 1-4 on the corroding surface. Interestingly, complex 2 containing $\mathrm{Fe}(\mathrm{III})$ metal ion shows much lower efficiencies than the other complexes, this may be attributed to the fact that in case of iron complex, iron itself forms a layer over a corroding surface thus instead of inhibition it itself get corroded. It is apparent that corrosion rate decrease as time passes and corrosion inhibition efficiency increased with time ${ }^{42}$. Corrosion parameters namely, corrosion rate (CR), corrosion inhibition efficiency $(\eta \%)$ and surface coverage $(\theta)$ were calculated and shown in Table 6. A comparative corrosion rate and corrosion efficiency data of all the compounds were presented in Figure 14 and 15. Corrosion inhibition efficiency rate follows the order BENZOEN $>\mathbf{4}>\mathbf{3}>\mathbf{1}>\mathbf{2}$. Corrosion inhibition efficiency of complex $\mathbf{4}$ was quite higher than other complexes and slightly smaller than ligand BENZOEN.

Table 6. Corrosion parameters of mild steel in $\mathrm{HCl}$ solution in the presence and absence of inhibitor at different time interval, obtained from weight loss measurements

\begin{tabular}{cccccccccc}
\hline \multirow{2}{*}{ Ligand/Complexes } & \multicolumn{3}{c}{$\begin{array}{c}\text { Corrosion rate, } \\
\mathrm{mg} \mathrm{cm}^{-2} \mathrm{~h}^{-1}\end{array}$} & \multicolumn{3}{c}{$\begin{array}{c}\text { Corrosion inhibition } \\
\text { efficiency } \eta \%\end{array}$} & \multicolumn{2}{c}{ Surface coverage, $\theta$} \\
& $6 \mathrm{~h}$ & $12 \mathrm{~h}$ & $24 \mathrm{~h}$ & $6 \mathrm{~h}$ & $12 \mathrm{~h}$ & $24 \mathrm{~h}$ & $6 \mathrm{~h}$ & $12 \mathrm{~h}$ & $24 \mathrm{~h}$ \\
BENZOEN & 14.51 & 8.36 & 6.36 & 60.93 & 77.47 & 82.36 & 0.60 & 0.77 & 0.82 \\
Complex 1 & 23.61 & 12.95 & 9.44 & 43.17 & 65.88 & 68.74 & 0.43 & 0.65 & 0.43 \\
Complex 2 & 25.41 & 15.45 & 11.6 & 31.58 & 58.41 & 61.59 & 0.31 & 0.58 & 0.61 \\
Complex 3 & 21.67 & 12.67 & 9.72 & 63.44 & 65.14 & 70.57 & 0.63 & 0.65 & 0.70 \\
Complex 4 & 16.04 & 9.72 & 7.33 & 56.82 & 73.83 & 78.77 & 0.56 & 0.73 & 0.78 \\
\hline
\end{tabular}

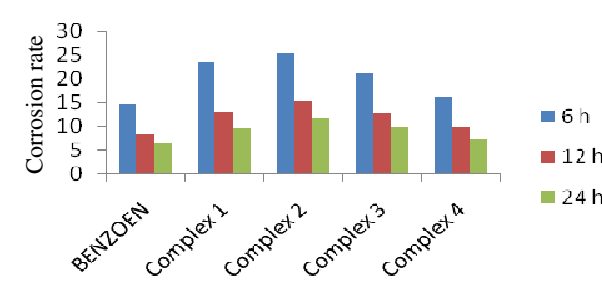

Figure 14. Corrosion rate of compounds

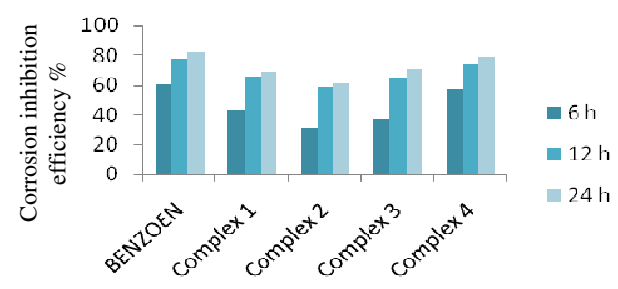

Figure 15. Corrosion inhibition efficiency of compounds

\section{Biological applications}

\section{Experimental study of in vitro catalase-like activity}

In a typical experiment, the tendency of catalase like activity of ligand and complexes 1-4 to decompose hydrogen peroxide into $\mathrm{H}_{2} \mathrm{O}$ and $\mathrm{O}_{2}$ was investigated in $\mathrm{CH}_{3} \mathrm{CN}$ by measuring 
volume of evolve dioxygen. Experiment has been carried out by taking $20 \mathrm{~mL}$ of $30 \% \mathrm{H}_{2} \mathrm{O}_{2}$ in a Kitassato flask and adding a complexes $\left(5 \mathrm{~mL}, 1 \mathrm{mmol}\right.$ in $\left.\mathrm{CH}_{3} \mathrm{CN}\right)$ with the help of a syringe through a rubber septum. Immediately, after the addition of complex, decomposition of $\mathrm{H}_{2} \mathrm{O}_{2}$ starts and volume of dioxygen evolve is measured from a graduated burette. The complete reaction was monitored for 14 minute and amount of dioxygen evolved for different complexes is shown in Figure 16. It was observed that catalase being a natural enzyme evolve $4.19 \times 10^{-1} \mathrm{~mol}$ of dioxygen. In complex 1, 2, 3 and 4 the amount of dioxygen evolve are $3.39 \times 10^{-1}, 2.90 \times 10^{-1}, 2.58 \times 10^{-1}$ and $2.18 \times 10^{-1}$ mol respectievely. The order of hydrogen peroxide decomposition is Catalase $>\mathbf{1}>\mathbf{2}>\mathbf{3}>\mathbf{4}$.

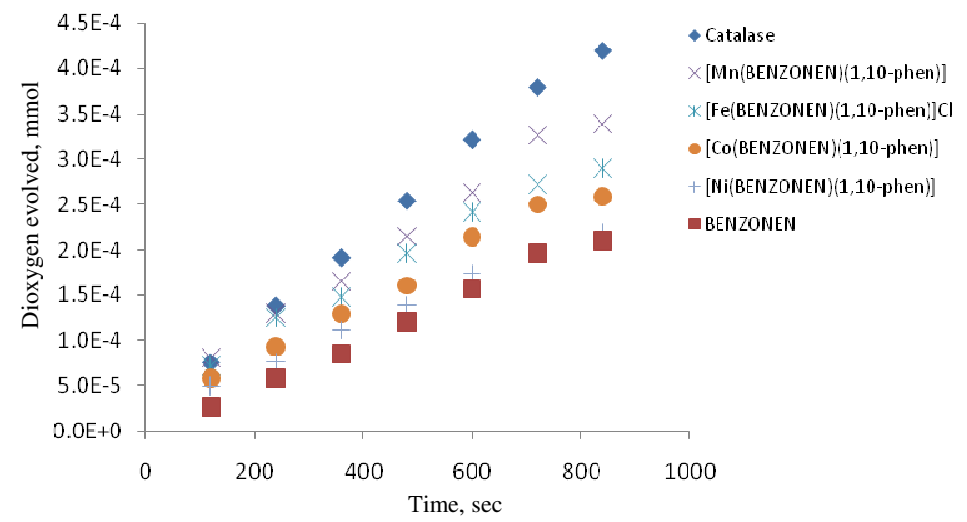

Figure 16. Time courses (second) of dioxygen evolution (mmol) in the disproportionation of $\mathrm{H}_{2} \mathrm{O}_{2}$

Since, the manganese complex 1 exhibit highest evolved dioxygen, the initial rate of $\mathrm{H}_{2} \mathrm{O}_{2}$ disproportionation by complex 1 was calculated by the further experiment. Plot of evolve dioxygen against time for different concentration of hydrogen peroxide is shown in Figure 17. An experiment using 1 as catalyst in $\mathrm{CH}_{3} \mathrm{CN}$ at $25{ }^{\circ} \mathrm{C}$ was also performed and after $14 \mathrm{~min}$ at $[\text { Complex } 1]_{0}=5 \times 10^{-3} \mathrm{~mol} \mathrm{dm}^{-3}$ and $\left[\mathrm{H}_{2} \mathrm{O}_{2}\right]_{0}=1 \times 10^{-3}, 2 \times 10^{-3}, 4 \times 10^{-3}$ and $8 \times 10^{-3} \mathrm{~mol} \mathrm{dm}^{-3}$ concentration, $3.34 \times 10^{-4}, 3.92 \times 10^{-4}, 4.82 \times 10^{-4}$ and $6.15 \times 10^{-4} \mathrm{mmol}$ of dioxygen was evolved respectively.

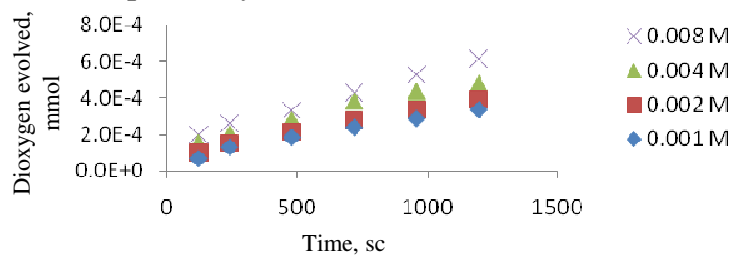

Figure 17. Time (sec) dependence of $\mathrm{O}_{2}$ evolution (mmol) at different concentrations of $\mathrm{H}_{2} \mathrm{O}_{2}$

Kinetics of the $\mathrm{H}_{2} \mathrm{O}_{2}$ disproportionation reactions

On experimental data Michaelis Menten equation was applied (Figure 18 and 19). The obtained catalytic turnover $\left(k_{c a t}\right)$ and Michaelis constant $\left(\mathrm{K}_{\mathrm{m}}\right)$ were $k_{c a t}=7.6 \times 10^{-2} \mathrm{~s}^{-1}$ and $\mathrm{K}_{\mathrm{m}}=6.65 \times 10^{-4} \mathrm{~mol} \mathrm{~L}^{-1}$. The catalytic efficiency $\varepsilon$ of an enzyme is the ratio $k_{c a} / K_{m}$. The higher the value of catalytic efficiency the more efficient is the enzyme. On the basis of the $k_{c a l} / K_{m}$ criterion, complex 1 with $k_{c a t} / K_{m}=1.142 \times 10^{2} \mathrm{~L} \mathrm{~mol}^{-1} \mathrm{~s}^{-1}$ is the efficient catalyst for $\mathrm{H}_{2} \mathrm{O}_{2}$ disproportionation. The related kinetics parameters for synthetic CAT models and enzyme are givin in Table 7. 


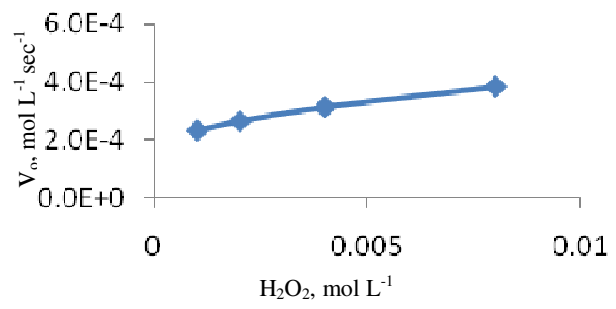

Figure 18. $\mathrm{v}_{\mathrm{o}}\left(\mathrm{mol} \mathrm{L}^{-1} \mathrm{~s}^{-1}\right)$ of $\mathrm{O}_{2}$ evolution as a function of different $\left[\mathrm{H}_{2} \mathrm{O}_{2}\right]$

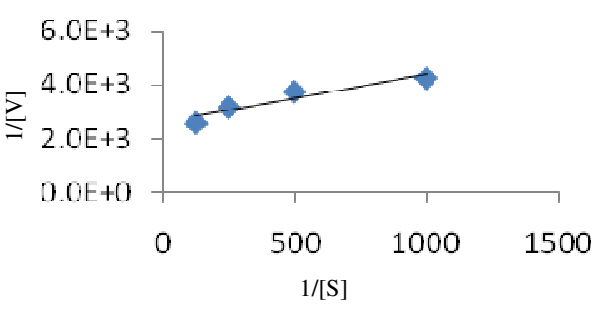

Figure 19. Lineweaver-Burk plot, a $\mathrm{H}_{2} \mathrm{O}_{2}$ saturation kinetics for complex 1 fitted to the Michaelis-Menten equation

Table 7. Related kinetics parameters for synthetic CAT models and enzyme

\begin{tabular}{|c|c|c|c|c|c|c|}
\hline S.No. & Catalyst/Enzyme & $\mathrm{K}_{\mathrm{m}}, \mathrm{mol} \mathrm{L}^{-1}$ & $\mathrm{~K}_{\mathrm{cat}}, \sec ^{-1}$ & $\begin{array}{l}\mathrm{K}_{\mathrm{cat}} / \mathrm{K}_{\mathrm{m}} \text { or } \\
\varepsilon \mathrm{mol}^{-1} \mathrm{~L} \\
\sec ^{-1}\end{array}$ & $\begin{array}{c}\text { Solvent, } \\
\text { Temprature, }{ }^{\circ} \mathrm{C}\end{array}$ & Reference \\
\hline 1. & Complex 1 & $6.65 \times 10^{-4}$ & $7.60 \times 10^{-2}$ & $2.142 \times 10^{2}$ & $\mathrm{CH}_{3} \mathrm{CN}, 25$ & this work \\
\hline 2. & Catalase & $2.5 \times 10^{-4}$ & $1.2 \times 10^{3}$ & $5.0 \times 10^{8}$ & $\mathrm{H}_{2} \mathrm{O}_{2} / \mathrm{H}_{2} \mathrm{O}$ & [43] \\
\hline 3. & T. thermophiles & $0.083(0.008)$ & $2.6 \times 10^{5}$ & $3.13 \times 10^{6}$ & $\mathrm{H}_{2} \mathrm{O}$ & [44] \\
\hline 4. & T. album & 0.015 & $2.6 \times 10^{4}$ & $1.73 \times 10^{6}$ & $\mathrm{H}_{2} \mathrm{O}$ & [44] \\
\hline 5. & L. plantarum & 0.35 & $2 \times 10^{5}$ & $0.57 \times 10^{6}$ & $\mathrm{H}_{2} \mathrm{O}$ & [44] \\
\hline 6. & $\begin{array}{l}\mathrm{Na}\left[\mathrm{Mn}_{2}\left(3-\mathrm{Me}-5-\mathrm{SO}_{3}-\right.\right. \\
\text { salpentO })(\mu-\mathrm{OAc})(\mu- \\
\left.\mathrm{OMe})\left(\mathrm{H}_{2} \mathrm{O}\right)\right] \cdot 4 \mathrm{H}_{2} \mathrm{O}\end{array}$ & $6.6(4)$ & $10.5(2)$ & $16(1) \times 10^{2}$ & $\begin{array}{c}\mathrm{H}_{2} \mathrm{O}(\mathrm{pH} 10.6), \\
25\end{array}$ & [45] \\
\hline 7. & {$[\mathrm{Mn}(\mathrm{X} \text {-salpnO })]_{2}$} & $10-102$ & $4.2-21.9$ & $305-990$ & $\mathrm{CH}_{3} \mathrm{CN}, 25$ & [45] \\
\hline
\end{tabular}

Complex $\mathbf{1}=[\mathrm{Mn}(B E N Z O N E N)(1,10-$ phen $)]$, ligands: BENZOEN $=(2 Z)-2-((E)-2-(1,2-$ diphenylethylideneamino)ethylimino)-1,2-diphenylethanol, 3-Me-5-SO ${ }_{3}$-salpent $\mathrm{OH}=1,5$-bis(3-methyl-5-sulphonatosalicylideneamino)pentan-3-ol; salpnOH = 1,3-bis(salicylideneamino)propan-2-ol

\section{Antibacterial assessment}

All the compounds showed considerable bactericidal activity against E. coli. The in vitro antibacterial activity of the BENZOEN and complex 1-4 were tested using the agar well diffusion method. Amoxicillin was used as positive standards and DMSO was used as negative control for this antibacterial activity. Activities of the ligand and complexes can be explained on the basis of Tweedy's chelation theory ${ }^{46}$. Chelation of Schiff base with metal ion will enhance the lipophilicity of the central metal atom, which subsequently favours its permeation through the lipid layers of the cell membrane and blocking the metal binding sites on enzymes of microorganisms. The growth inhibition zones were measured in diameter $(\mathrm{mm})$ and the results are listed in Table 8. All the tested compounds showed good antibacterial activity against the selected microorganism $E$. coli. The obtained results indicate that the complexes were more effective against $E$. coli under identical experimental conditions. Iron(III) complex has higher bacterial activity than the other complexes. The bioactivity of the ligand and their complexes is found to be order $\mathbf{2}>\mathbf{3}>\mathbf{1}>\mathbf{4}>$ BENZOEN.

\section{Minimum inhibitory concentration (MIC)}

The MIC of the complexes and ligand is also displayed in the Table 8. Since, the MIC is the concentration of the highest dilution tube, in which bacterial growth was absent. It was observed that complex 1-4 has exhibited MIC in between $0.43-0.55 \mu \mathrm{g} / \mathrm{mL}$, which was 
higher than standard drug chloramphenicol but lower than amoxicillin. It was also observed that the complex 2 was most active to inhibit bacteria with inhibition zone of $31 \mathrm{~mm}$ and also lowest minimum inhibitory concentration of $0.43 \mu \mathrm{g} / \mathrm{mL}$ MIC of the complexes follows trend as $\mathbf{4}>\mathbf{1}>\mathbf{3}>\mathbf{2}$.

Table 8. Antibacterial screening data of BENZOEN and complexes 1-4 against $E$ coli

\begin{tabular}{ccccc}
\hline S. No. & Ligands/Complexes & $\begin{array}{c}\text { Diameter of inhibition } \\
\text { zone, in mm }\end{array}$ & $\begin{array}{c}\text { MIC, } \\
\mu \mathrm{g} / \mathrm{mL}\end{array}$ & Reference \\
\cline { 1 - 4 } 1. & Standard: Amoxicillin & 41 & 0.62 & {$[47]$} \\
2. & BENZOEN & 19 & - & this work \\
3. & Complex 1 & 26 & 0.49 & this work \\
4. & Complex 2 & 31 & 0.43 & this work \\
5. & Complex 3 & 28 & 0.44 & this work \\
6. & Complex 4 & 22 & 0.55 & this work \\
\hline
\end{tabular}

\section{Conclusion}

Synthesis and characterization of BENZOEN and its four mixed ligand complexes of $\mathrm{Mn}(\mathrm{II}), \mathrm{Fe}(\mathrm{III}), \mathrm{Co}(\mathrm{II})$ and $\mathrm{Ni}(\mathrm{II})$ containing 1, 10-phenanthroline as $N, N^{\prime}$ donor ligand was studied. The geometries of complexes have also been optimized by DFT and TDDFT calculations. The corrosion inhibition behavior of ligand and complexes has also been studied for mild steel in $0.5 \mathrm{M} \mathrm{HCl}$ medium. Ligand and complex 4 exhibit good anticorrosive activity. The synthesized compounds were also tested as catalysts for $\mathrm{H}_{2} \mathrm{O}_{2}$ decomposition. Enzyme kinetics study performed has proved that to some extent these complexes, especially complex $\mathbf{1}$ in solution mimic like catalase in disproportionation reaction of $\mathrm{H}_{2} \mathrm{O}_{2}$. Antibacterial activity of ligand and complexes indicate that activity of ligand become more pronounced when coordinated with the metal ions. Hence, from all these extensive studies, it may be concluded that some of these complexes could be exploited for the design of novel anticorrosive material, antibacterial drug as well as catalytic material for excavanging of peroxide formed in biological system.

\section{Acknowledgement}

The authors are grateful to Principal Government Science College, Jabalpur and Head, Chemistry Department for providing necessary laboratory facilities. We sincerely thanks SAIF-CDRI Lucknow, for recording ESI-MS, ${ }^{1} \mathrm{H}$ NMR, ${ }^{13} \mathrm{C}$ NMR. One of us (Preeti Vaidya) is also grateful to the UGC-New Delhi for financial support through RGNF (Award letter no. F1-17.1/2015-16/RGNF-2015-17-SC-MAD-13266/(SAIII/Website)).

\section{References}

1. Khan M I, Khan A, Hussain I, Khan M A, Gul S, Iqbal M, Ur-Rahman I and Khuda F, Inorg Chem Commun., 2013, 35, 104-109; DOI:10.1016/j.inoche.2013.06.014

2. Williams N J, Gan W, Reibenspies J H and Hancock R D, Inorg Chem., 2009, 48(4), 1407-1415; DOI:10.1021/ic801403s

3. Elemike E E, Nwankwo U H, Onwudiwe C D and Hosten C E, J Mol Structr., 2017, 1147, 252-265; DOI:10.1016/j.molstruc.2017.06.104

4. Parkin G, Chem Rev., 2004, 104(2), 699-767; DOI:10.1021/cr0206263

5. Ali O A M, Abd El Wahab Z H and Ismail B A, J Mol Structr., 2017, 1139, 175-195; DOI:10.1016/j.molstruc.2017.03.025 
6. Demertzi D K, Domopoulou A, Demertzis M A, Valle G and Papageorgiou A, $J$ Inorg Biochem., 1997, 68(2), 147- 155; DOI:10.1016/S0162-0134(97)00087-1

7. Khan S A and Yusuf M, J Med E Chem., 2009, 44(5), 2270-2274; DOI:10.1016/j.ejmech.2008.06.008

8. Hanawa T, Asayama S, Watanabe T, Owada S and Kawakamai H, J Contr Rel., 2009, 135(1), 60-64; DOI:10.1016/j.jconrel.2008.12.012

9. Brazier M W, Doctrow S R, Masters C L and Collins S J, Free Radical Biol. Med., 2008, 45(2), 184-192; DOI:10.1016/j.freeradbiomed.2008.04.006

10. Dede B, Karipcin F and Cengiz M, J Hazard Mater., 2009, 163(2-3), 1148-1156; DOI:10.1016/j.jhazmat.2008.07.070

11. Panja A, Jana N C, Patra M, Brandao P, Moore C E, Eichhorn D M and Frontera A, $J$ Mol Catal A: Chem., 2016, 412, 56-66; DOI:10.1016/j.molcata.2015.11.008

12. Jana N C, Brandao P and Panja A, J Inorg Biochem., 2016, 159, 96-106; DOI:10.1016/j.jinorgbio.2016.02.038

13. Abd El-Halim H F, Mohamed G G and Khalil E A M, J Mol Struct., 2017, 1146, 153 163; DOI:10.1016/j.molstruc.2017.05.092

14. Bazán S, Pérez A, Carpio E D, Hernández L, Madden W and Lubes V, J Mol Liq., 2016, 215, 265-268; DOI:10.1016/j.molliq.2015.12.045

15. Accorsi G, Listorti A, Yoosaf A K and Armaroli N, Chem Soc Rev., 2009, 38, 16901700; DOI:10.1039/B806408N

16. McCann M, Kellett A, Kavanagh K, Devereux M and Santos A L S, Cur Med Chem., 2012, 19(17), 2703-2714, DOI:10.2174/092986712800609733

17. El-Shahawi M S, Al-Jahdali M S, Bashammakh A S, Al-Sibaai A A and Nassef H M, Spectrochim. Acta, Part A., 2013, 113, 459-465, DOI:10.1016/j.saa.2013.04.090

18. Raman N, Selvan A and Sudharsan S, Spectrochim Acta, Part A., 2011, 79(5), 873883; DOI:10.1016/j.saa.2011.03.017

19. Nair R, Shah A, Baluja S and Chanda S, J Serb Chem Soc., 2006, 71 (7), 733-744; DOI:10.2298/JSC0607733N

20. Jeffery G H, Bassett J, Mendham J, Denney R C, Vogel A I, Textbook of Quantitative Inorganic Analysis, $5^{\text {th }}$ Ed; 1989, pp 454-462.

21. Frisch M J, Trucks G W, Schlegel H B, Scuseria G E, Robb M A, Cheeseman J R, Scalmani G, Barone V, Mennucci B, Petersson G A, Nakatsuji H, Caricato M and Li X, Gaussian 09, Revision D.01, Gaussian Inc., Wallingford CT, (2009).

22. Becke A D, Phys Rev A, 1988, 38(6), 3098, DOI:10.1103/PhysRevA.38.3098

23. Lee C, Yang W and Parr R G, Phys Rev B, 1988, 37(2), 785;

DOI:10.1103/PhysRevB.37.785

24. Tang B, Ye J and Ju X, ISRN Organic Chemistry, 2011, DOI:10.5402/2011/920753

25. Mishra M, Tiwari K, Mourya P, Singh M M and Singh V P, Polyhedron, 2015, 89, 29-38; DOI:10.1016/j.poly.2015.01.003

26. Pelczar M J, Chan E C S and Krieg N R, Text Book of Microbiology; $5^{\text {th }}$ Ed.; McGraw-Hill Publishing Company Ltd.; New Delhi, India, 2001, pp 138.

27. Mehrotra R, Shukla S N and Gaur P, J Coord Chem., 2015, 68(4), 650-661; DOI:10.1080/00958972.2014.999053

28. Silverstein R M, Bassler G C and Morrill T C, Spectrometric Identification of Organic Compound; John Wiley and Sons, inc: New York, 1991, 82-108, 123-131, 219-262.

29. Arunagiri C, Subashini A, Saranya M, Muthiah P T, Thanigaimani K and Abdul Razak I, Spectrochim Acta, Part A., 2015, 135, 307-316; DOI:10.1016/j.saa.2014.07.016 
30. Geary W J, Coord Chem Rev., 1971, 7(1), 81-122; DOI:10.1016/S00108545(00)80009-0

31. Orojloo M, Zolgharnein P, Solimannejad M and Amani S, Inorg Chim Acta, 2017, 467, 227-237; DOI:10.1016/j.ica.2017.08.016

32. Sawant V A, Gotpagar S N, Yamgar B A, Sawant S K, Kankariya R D and Chavan S S, Spectrochim Acta, Part A., 2009, 72(3), 663-669, DOI:10.1016/j.saa.2008.11.004

33. Shebl M, Khalil S M E and Al-Gohani F S, J Mol Struct., 2010, 980(1-3), 78-87, DOI:10.1016/j.molstruc.2010.06.040

34. Singh P P, Coord Chem Rev., 1980, 32(1), 35-65; DOI:10.1016/S00108545(00)80369-0

35. Greenwood N N and Earnshaw A, Chemistry of the ELEMENTS, First Edn., Pergamon Press, New York, 1984.

36. Ekennia A C, Osowole A A, Olasunkanmi L O, Onwudiwe D C, Olubiyi O O and Ebenso E E, J Mol Struct., 2017, 1150, 279, 292; DOI:10.1016/j.molstruc.2017.08.085

37. Shoba D, Periandy S, Karabacak M and Ramalingam S, Spectrochim Acta, Part A, 2011, 83(1), 540-552, DOI:10.1016/j.saa.2011.09.002

38. Sun Y, Chen X, Sun L, Guo X and Lu W, J Chem Phys Lett., 2003, 381(3-4), 397403, DOI:10.1016/j.cplett.2003.09.115

39. Mulliken R S, J Chem Phys., 1995, 23, 1833; DOI:10.1063/1.1740588

40. Billes F, Holmgren A and Mikosch H, Vib Spectro., 2010, 53(52), 296-306, DOI:10.1016/j.vibspec.2010.04.011

41. Ramalingam S, Periandy S, Karabacak M and Karthikeyan N, Spectrochim Acta, Part A, 2013, 104, 337-351, DOI:10.1016/j.saa.2012.11.107

42. Saha S K, Dutta A, Ghosh P, Sukul D and Banerjee P, PCCP, 2016, 18,17898-911, DOI:10.1039/c6cp01993e

43. Buxbaum E, Fundamentals of Protein Structure and Function, Second Ed., Spriger, 2015, 5, 118.

44. Shank M, Barynin V and Dismukes G C, Biochem., 1994, 33(51), 15433-15436, DOI:10.1021/bi00255a025

45. Larson E J and Pecoraro V L, J Am Chem SOC., 1991, 113(10), 3810-3818, DOI:10.1021/ja00010a025

46. Shukla S N, Gaur P, Rai N, Mehrotra R, Chaurasia B, Gupta J P and Sinha B K, Chem Sci Trans., 2017, 6(4), 545-560; DOI:10.7598/cst2017.1415

47. Ejidike I P and Ajibade P A, Molecules, 2015, 20(6), 9788-9802, DOI:10.3390/molecules20069788 